OPEN ACCESS

Edited by:

Antonia Nostro,

University of Messina, Italy

Reviewed by:

Liangju Kuang,

Harvard Medical School,

United States

Brendan M. Leung,

Dalhousie University, Canada

${ }^{*}$ Correspondence:

Livia Visai

livia.visai@unipv.it

${ }^{\dagger}$ These authors share first authorship

Specialty section: This article was submitted to Biomaterials,

a section of the journal Frontiers in Bioengineering and

Biotechnology

Received: 29 February 2020

Accepted: 28 September 2020

Published: 20 October 2020

Citation:

Oriano M, Zorzetto L,

Guagliano G, Bertoglio F, van Uden S, Visai $L$ and Petrini P (2020) The Open

Challenge of in vitro Modeling

Complex and Multi-Microbial Communities in Three-Dimensional

Niches.

Front. Bioeng. Biotechnol. 8:539319.

doi: 10.3389/fbioe.2020.539319

\section{The Open Challenge of in vitro Modeling Complex and Multi-Microbial Communities in Three-Dimensional Niches}

\author{
Martina Oriano ${ }^{1,2,3+}$, Laura Zorzetto ${ }^{4 \dagger}$, Giuseppe Guagliano ${ }^{5}$, Federico Bertoglio ${ }^{1,6}$, \\ Sebastião van Uden ${ }^{5}$, Livia Visai ${ }^{1,7 *}$ and Paola Petrini ${ }^{5}$
}

${ }^{1}$ Molecular Medicine Department (DMM), Center for Health Technologies (CHT), UdR INSTM, University of Pavia, Pavia, Italy, ${ }^{2}$ Department of Pathophysiology and Transplantation, University of Milan, Milan, Italy, ${ }^{3}$ Internal Medicine Department, Respiratory Unit and Adult Cystic Fibrosis Center, Fondazione IRCCS Ca' Granda Ospedale Maggiore Policlinico, Milan, Italy, ${ }^{4}$ Department of Biomaterials, Max Planck Institute of Colloids and Interfaces, Potsdam, Germany, ${ }^{5}$ Department of Chemistry, Materials and Chemical Engineering "Giulio Natta" and UdR INSTM Politecnico di Milano, Milan, Italy, ${ }^{6}$ Technische Universität Braunschweig, Institute of Biochemistry, Biotechnology and Bioinformatic, Department of Biotechnology, Braunschweig, Germany, ${ }^{7}$ Department of Occupational Medicine, Toxicology and Environmental Risks, Istituti Clinici Scientifici (ICS) Maugeri, IRCCS, Pavia, Italy

The comprehension of the underlying mechanisms of the interactions within microbial communities represents a major challenge to be faced to control their outcome. Joint efforts of in vitro, in vivo and ecological models are crucial to controlling human health, including chronic infections. In a broader perspective, considering that polymicrobial communities are ubiquitous in nature, the understanding of these mechanisms is the groundwork to control and modulate bacterial response to any environmental condition. The reduction of the complex nature of communities of microorganisms to a single bacterial strain could not suffice to recapitulate the in vivo situation observed in mammals. Furthermore, some bacteria can adapt to various physiological or arduous environments embedding themselves in three-dimensional matrices, secluding from the external environment. Considering the increasing awareness that dynamic complex and dynamic population of microorganisms (microbiota), inhabiting different apparatuses, regulate different health states and protect against pathogen infections in a fragile and dynamic equilibrium, we underline the need to produce models to mimic the threedimensional niches in which bacteria, and microorganisms in general, self-organize within a microbial consortium, strive and compete. This review mainly focuses, as a case study, to lung pathology-related dysbiosis and life-threatening diseases such as cystic fibrosis and bronchiectasis, where the co-presence of different bacteria and the altered 3D-environment, can be considered as worst-cases for chronic polymicrobial infections. We illustrate the state-of-art strategies used to study biofilms and bacterial niches in chronic infections, and multispecies ecological competition. Although far from the rendering of the 3D-environments and the polymicrobial nature of the infections, they 
represent the starting point to face their complexity. The increase of knowledge respect to the above aspects could positively affect the actual healthcare scenario. Indeed, infections are becoming a serious threat, due to the increasing bacterial resistance and the slow release of novel antibiotics on the market.

Keywords: polymicrobial cultures, chronic infections, antimicrobial, antibiotic resistance, in vitro models, ecological models, lung dysbiosis, biofilm

\section{THE NEED FOR PLATFORMS FOR POLYMICROBIAL CULTURE}

Pure bacteria cultures are an unnaturally occurring scenario. Like all organisms, bacteria live as part of an ecosystem, sharing, exchanging and competing for resources with other microorganisms present in their environment (Freilich et al., 2010). This fact is combined with the mechanical, morphological and biochemical conditions of the microenvironment, leading to a biochemical action-reaction effect that changes the way bacteria communities respond to drastic events (Raimbault, 1998; Tuson et al., 2012). Specifically, bacterial ecosystems are mainly organized in three-dimensional matrices, either self-produced, like biofilms, either otherwise produced, like mucus. As a result, for example, in vitro pure bacteria culture in suspension in a medium (planktonic conditions) is significantly more susceptible to antibiotic treatment than an in vivo infection where the same bacterial strain is the dominant pathological agent. So much so that when a certain antibiotic is screened to be potentially effective to treat a patient, the needed antibiotic concentration to be delivered to the infection site must be 100 to 1000 times higher than the antibiotic concentration assessed in the susceptibility test (Macià et al., 2014).

These factual cues reveal the inability of in vitro culturing methods to provide the means for hosting the complexity of natural microbial environments. New technological and methodological tools are quested to enable the study of microbial communities in a reproducible and controlled manner, either in vitro or in silico. The aim of this is boosting the understanding of the dynamic mechanisms underlying the way that bacterial communities react and evolve in response to external stimuli and to study their delicate equilibrium within any environment, including the human body. These methods could work in synergy with proper in vivo models. Diverse applicative fields can benefit from the new methodological tools: the study of the effect of drugs, nutrients, prebiotics and probiotics on the gastrointestinal microbiota, or the effectiveness of antimicrobial treatments. The understanding of the underlying mechanisms precedes the deliberate control and modulation of the response, avoiding trialand-error approaches based on phenomenological observations.

Abbreviations: BBC, Biofilm Bactericidal Concentration; BHI, Brain Heart Infusion; BPC, Biofilm Preventing Concentration; CF, cystic fibrosis; CFU, colony forming units; CL, closed system; CLSM, Confocal Laser Scanning Microscope; FISH, fluorescence in situ hybridization; LB, Lysogeny Broth; MBC, Minimal Bactericidal Concentration; MBEC, Minimal Biofilm Eradication Concentration; MBIC, Minimal Biofilm Inhibitory Concentration; MEM, Minimal Essential Medium; MIC, Minimal Inhibitory Concentration; MTT, 3-(4,5-dimethylthiazol2-yl)-2,5-diphenyltetrazolium bromide; OP, open system; qPCR, Real TimePCR; TSB, Tryptic Soy Broth; XTT, sodium 3'-[1- (phenylaminocarbonyl)- 3,4tetrazolium]-bis (4-methoxy6-nitro) benzene sulfonic acid hydrate.
The development of new methods originates from the parallel study of the natural microbial environments that are still mainly unexplored. We will address the bacterial niches in the human body with a specific highlight on the lung environments and chronic and multiple infections, as they represent one of the most challenging issues to be addressed. In these cases, the changes in the microenvironment are related to the change of the dynamics of the multistrain interactions. This paper addresses the complexity of the polymicrobial systems in the human body, with a specific focus on challenging polymicrobial infections. We describe the state of the art of in vitro and mathematical models as powerful tools to investigate the natural complexity. Their multifaceted potential can influence diverse application fields. Among them, we focused on the fight against infectious diseases either by personalized testing of the efficacy of antimicrobial substances or the development of new therapeutic approaches.

\section{D-BACTERIAL NICHES IN THE HUMAN BODY}

Each species in an ecosystem is thought to occupy a separate, unique niche. The ecological niche of a microorganism describes how it responds to the distribution of resources and competing species, as well as how it alters those same factors in turn. The niche is a complex description of how a microbial species uses its environment. In nature, bacteria interact in complex communities, with the contemporary presence of different species whose abundance fluctuates over time in response to their mutual interaction and to the surrounding environment. Their interaction can lead to competition or cooperation to achieve an evolutionary advantage. The complex microbial communities, also known as microbiota, are fundamental in the human body development and the presence of dysregulation of the microbial community is associated with different disease states. Human gut microbiota, for example, has important functions in the development of immunity, defenses against pathogens, host nutrition including the production of short-chain fatty acids, synthesis of vitamins, making it an essential component of the human body (Bauer et al., 1963; Amon and Sanderson, 2017). Moreover, the colonization from specific microorganisms can protect from parasites or other pathogens: S. epidermidis on the skin, for example, promotes the production of transmembrane proteins and cytokines involved in the immune response and ultimately protects against infection with the parasite Leishmania major (Naik et al., 2012). 
Various biological environments in the human body host microbial communities (Costello et al., 2012), yet, for its clinical relevance, our focus is on the lung environment and its pathologies.

\section{Lung Microbiota and Its Dysregulation in Pathological Conditions}

Lungs were thought for many years as sterile, being the respiratory tract less charged in genetic material than other body districts, i.e., gastrointestinal or urinary tract. Nowadays, we know that the lungs have a physiological microbiome (Sze et al., 2015; Wang et al., 2016; Segal et al., 2017). Lungs are in constant communication with the external environment with continuous microbe immigration and elimination through mucociliary clearance, although a resident flora is present even in the lungs of healthy subjects (Hilty et al., 2010; Morris et al., 2013; Bassis et al., 2015; Dickson et al., 2015).

Lungs are not the ideal location for bacterial proliferation in comparison to the intestinal tract, because they are low-nutrient sites and their physiological conditions related to oxygen tension, $\mathrm{pH}$, temperature and inflammatory cell infiltration can vary. These conditions determine a continuous change in the microbial pulmonary ecosystem (West, 1968; Ingenito et al., 1987).

The presence of lung microbiota was identified after the development of culture-independent techniques. The sequencing of highly conserved loci, like $16 \mathrm{~s}$ rRNA gene, through high throughput sequencing, is the most common technique for microbiome identification. Moreover, the development of bacterial genomes databases allowed the scientific community to assign a relative abundance of bacteria and diversity (Costa et al., 2018).

Lung microbiota develops in early life and it is specific for the method of delivery. Vaginal-delivered children's microbiota resulted to be mainly composed of Lactobacillus, Prevotella, or Sneathia species, while cesarean section born children acquired Staphylococcus, Corynebacterium, and Propionibacterium species (Dominguez-Bello et al., 2010). The early microbiota acquisition protects the lungs from responses to possibly inhaled antigens. Healthy lungs microbiota composition is dynamic and among the multiple bacteria present in the lungs, whose abundance and composition vary in time, bacteroidetes and firmicutes constitute a retained core (Erb-Downward et al., 2011; Morris et al., 2013; Segal et al., 2013).

Microbial diversity in the lungs seems to be crucial in the homeostasis of the respiratory system. Dysbiosis situations result in both acute and chronic diseases (Boyton et al., 2013; Surette, 2014; Mammen and Sethi, 2017).

The level of dysregulation may be correlated to disease severity and the dominance of a specific microorganism seems to be linked to the disease state (Venkataraman et al., 2015) (Figure 1). The predominance of a bacterial species in the lungs and a decrease of richness in microbiota seems to be associated with diseases like cystic fibrosis (CF) (de Dios Caballero et al., 2017; Zemanick et al., 2017). In both acute and chronic (bronchiectasis) diseases, the disease state is associated with the loss of bacterial diversity and the dominance of a single or a small group of taxa (Tunney et al., 2013).

Interestingly, chronic infections are correlated with a change in mucus viscosity, indicating the interdependence of the threedimensional matrix and the bacterial interspecies interactions. In the typical bacterial niches of CF and bronchiectasis, the chronic co-presence of different pathogens is a life-threatening issue. $\mathrm{CF}$ is a systemic disease caused by genetic mutations in which pulmonary implications are strictly related to disease severity and mortality. It involves airway surface liquid depletion producing mucus obstruction and chronic inflammation with persistent leukocyte accumulation at the pulmonary level (Cheung et al., 2008). Dehydrated, thickened secretions lead to endobronchial infection with a limited spectrum of distinctive bacteria, mainly Staphylococcus, Pseudomonas, and Burkholderia, an exaggerated inflammatory response leading to the development of bronchiectasis, progressive obstructive airways disease and frequent exacerbations (Guggino and Banks-Schlegel, 2004; Marshall et al., 2016). P. aeruginosa, which is one of the most frequent bacteria in CF, is also able to generate biofilm. Biofilm formation leads to further difficulty in antibiotic treatment. Burkholderia instead could be very dangerous in CF, due to their intrinsic antibiotic resistance, increasing lung disease severity. Infection from Burkholderia cepacia complex is also an exclusion criterion for lung transplants. Besides, continuous exposure to antibiotics is contributing to the insurgence of multidrug-resistant pathogens and studies are supporting a loss of microbiome diversity with age, due to antibiotics use with a parallel increase of disease severity (Knippenberg et al., 2015).

Bronchiectasis is a chronic respiratory disease characterized by permanent airway dilation with daily symptoms such as cough, sputum production, and recurrent exacerbations. The prevalence of bronchiectasis is up to 500/100,000 individuals increasing worldwide (Amati et al., 2017).

Bronchiectasis leads to a decreased mucus excretion and an overgrowth of microorganisms and this condition causes inflammation in the lungs. Infection and inflammation, that easily become chronic, leads to further damage to the airways and worsening of patients' conditions (Swenson et al., 2017). Bronchiectasis patients' lungs are colonized by several pathogens like Pseudomonas aeruginosa, Haemophilus influenzae, Moraxella catarrhalis, Escherichia species, Klebsiella species (Gram-negative) and Gram-positive as Streptococcus pneumoniae and Staphylococcus aureus detected though standard microbiology (Chalmers et al., 2014). Bronchiectasis etiology is very heterogeneous and identified as post-infectious in $20 \%$ of patients, caused by chronic obstructive pulmonary disease (COPD) in $15 \%, 10 \%$ as a cause of tissue diseases, $5.8 \%$ due to immunodeficiency and $3.3 \%$ linked to asthma. Identified causes cover $60 \%$ of patients, while in $40 \%$ of cases the cause of bronchiectasis is idiopathic (Amati et al., 2017). Microbiome analysis of low airways samples shows pronounced domination of proteobacteria including Pseudomonas and Haemophilus in association with neutrophil-mediated inflammation. In opposition, in the presence of lower neutrophilic inflammation and frequent exacerbations, the microbiome was dominated by firmicutes (Rogers et al., 2014; Taylor et al., 2015; Chalmers et al., 


\section{Physiological microbiota}

\section{Lung dysbiosis}
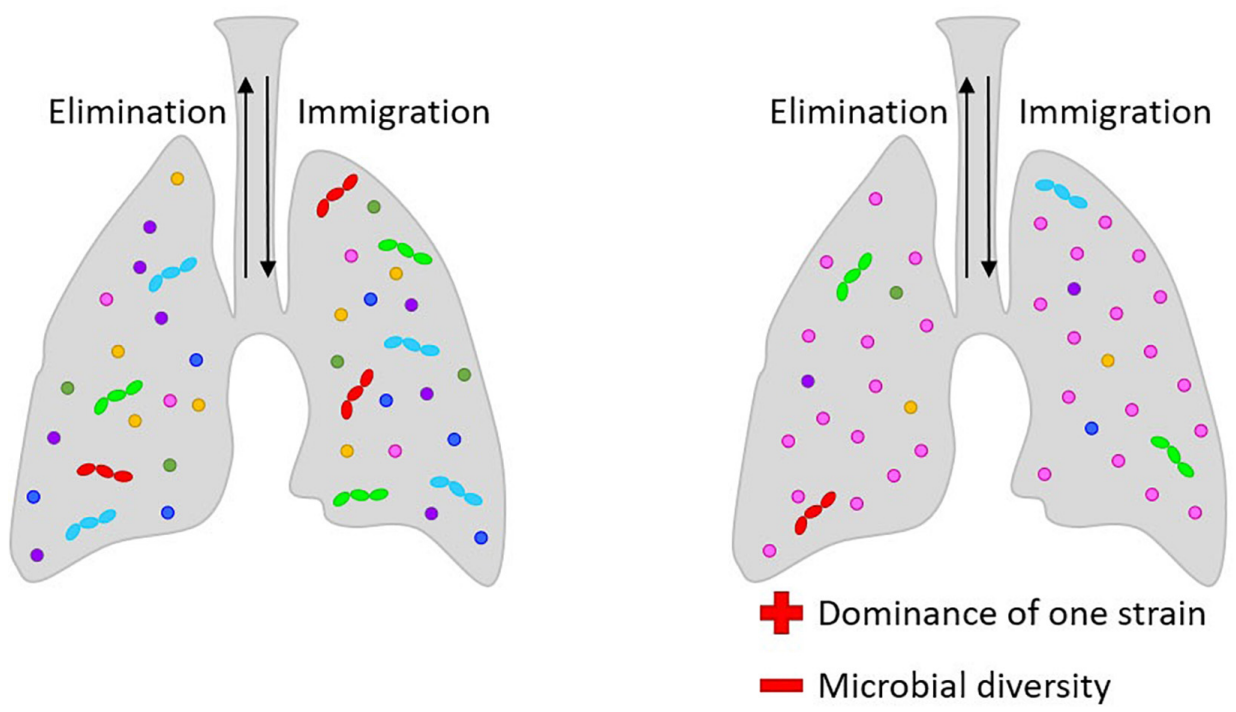

FIGURE 1 | Lung microbiota: in physiological conditions, its composition is dynamic and among the multiple bacteria present in the lungs; in pathological conditions, microbial diversity is lost, and dysbiosis situations result in both acute and chronic diseases, with the dominance of a single or a small group of taxa. In bronchiectasis, dehydrated, thickened secretions lead to endobronchial infection with a limited spectrum of distinctive bacteria, mainly Staphylococcus, Pseudomonas, and Burkholderia. In CF, the dominance of Pseudomonas aeruginosa and Burkholderia cepacea are related to the progression of the pathologies.

2017). Genera detected in lower airways through 16s rRNA gene sequencing during a stable state are usually Prevotella, Veillonella Streptococcus, Moraxella, Neisseria, Flavobacterium, Leptotrichia, Fusobacterium (Rogers et al., 2014; Lee et al., 2018).

Being interspecies interactions and the microbial niches crucial for the physiological conservation of the body homeostasis, both basic and translational studies in this field can result in clinical advances in the treatment of many diseases.

\section{ANTIBIOTIC RESISTANCE AND DRUG DEVELOPMENT IN LUNG DISEASES}

The lung microbiota is an ecosystem that can enter a state of dysbiosis when a pathological bacterium becomes dominant. Now the use of antibiotics is the traditional medical approach to treat this condition. Antibiotics are very useful in medicine, but aside their effect on target cause effects on the entire bacterial community that take time to recover. The remaining bacterial community becomes in severe need for rehabilitation until a new microbiota eubiosis is achieved.

Besides that, the awareness around the development of bacterial resistance to antibiotics is growing. Antibiograms are the tool used by clinicians and scientists to evaluate the susceptibility of bacterial isolates to antibiotics and are fundamental in diseases like CF or bronchiectasis where patients are constantly facing chronic respiratory infections (Swenson et al., 2017). In reality, susceptibility indicates that the tested antibiotic can neutralize the pathological bacteria culture in planktonic conditions at a concentration that is far lower than what would be required for infections in humans, and, as a consequence, its ability to control the infections is overestimated. Whether or not the treatment is effective, nonpathological bacteria communities, crucial for maintaining the symbiotic functions of the human microbiome, are severely debilitated or acquire the ability to resist such antibiotic class (Zhang et al., 2019).

Moreover, some bacteria are also able to form biofilms. Biofilms are bacterial communities that can develop in nature as well as in the human body, well-coordinated communities in which bacteria live in a self-produced extracellular matrix composed of exopolysaccharides, DNA and proteins (Costerton et al., 1995). CF lungs are a favorable place for biofilm formation given the properties of CF mucus. Biofilms in CF lungs can increase the spreading of antibiotic resistance among the community and also limit the bioavailability of drugs by inhalation creating a physical barrier. As mentioned above, $P$. aeruginosa is one of the most dangerous and frequent bacteria in $\mathrm{CF}$, able to install very resistant chronic infection and able to initiate biofilm formation (Moreau-Marquis et al., 2008).

\section{Development of Innovative Approaches for Combating Lung Infections}

The use of antibiotics to fight bacterial infections seems not to be the only strategy to face this problem. An alternative strategy, which neutralizes the pathological bacteria while contemporaneously leading the lung microbiota toward eubiosis could revolutionize the way lung infections are treated. This is precisely what new approaches using pre- and probiotics are aiming at. Strategies that employ manipulation of distal (gut) 
and local (lung) microbiomes to aid the host in combating a lung infection are proposed (Dumas et al., 2018). One strategy concerns the use of the immune-modulatory ability of the gut (distal) microbiome to allow the host to gain back control over the lung infection. Previous studies demonstrated the feasibility to recreate lung dysbiosis in mice, followed by seeding pathological bacteria - K. pneumoniae, S. pneumoniae and Mycobacterium tuberculosis - to model a severe lung infection in vivo. After delivering a fecal transplant, they noticed that the host restored control over the lung infection through increased immune system activity (Khan et al., 2016; Schuijt et al., 2016; Brown et al., 2017). This is one of the many surprising systemic effects of the intestinal microbiota. Not long ago it was assumed that a healthy lung was a sterile environment, now there is evidence indicating that not only it exists but also microbiome from distal body districts (e.g., gut) influences the stability of lung microbiota (Dumas et al., 2018).

The immunomodulation effect of certain bacteria, e.g., Lactobacillus genus, toward the well-being of their host is not restrained to a distal body district (Barbieri et al., 2013, 2017, 2019). These studies focus on the potential of administering probiotics directly over the infected region, to understand if these can establish a presence within the microbiota under a state of dysbiosis and assist in restoring control over the infection. They have infected the lungs of mice with S. pneumoniae, followed by nasal administration of Lactobacillus rhamnosus. It was observed that L. rhamnosus stimulates and increases the number of B cells (Barbieri et al., 2013), CD4 + T lymphocytes (Barbieri et al., 2017), macrophages and dendritic cells (Barbieri et al., 2019) in the lung, significantly improving the outcomes of pneumococcal infections. Although results are promising, clinical trials are needed to help understand if probiotics can be used as an aid to antibiotics in humans. Nevertheless, it provides another potential pathway to help solve the antibiotic crisis that is currently unfolding due to the rise of antimicrobial resistance (Hendriksen et al., 2019), led by the inability of antibiotic development stakeholders to bring new antibiotic classes to the market.

The health industry deals with bacterial infections by developing new testing methods and tailored strategies to fight infections; developing new bacterial culturing tools could increase their efficacy and broaden their range of applications. Improvement of in vitro efficacy screening seems to have the potential to enhance the development of new treatments.

\section{IN VITRO MODELING THE THREE DIMENSIONAL AND MULTIMICROBIAL COMMUNITIES}

In situ models would be the ideal solution to study biota and biofilm behavior in their native environment (Wimpenny, 1997) and test for novel antibiotics. Yet, in the case of bacterial related infection, such models are hardly attainable. Thus, researchers usually turn to in vitro and in vivo models. Focusing on the first type, there are two main approaches: a top-down approach, microcosms and a bottom-up approach, consortia (Figure 2) (Sissons, 1997; Wimpenny, 1997). In the microcosm approach, biological materials mimicking the target environment evolve in vitro: polymicrobial cultures from the natural biota, properly sampled from voluntary donors, are often used (Sissons, 1997; Lebeaux et al., 2013). In theory, this approach allows obtaining the most closely related model to the native conditions, but it is highly affected by inter- and intra-variability of donors and it can be easily influenced by the sampling methods (Sissons, 1997; Lebeaux et al., 2013). Moreover, among the sampled bacteria, strict anaerobes do not easily survive standard culture techniques (Woods et al., 2012) and the resulting flora of the model could be less well-representative of the native environment than initially thought. To study specific aspects of bacterial interactions, to exploit even simpler experimental models selecting the most relevant species to target a scientific question: this bottom-up approach can be labeled as 'consortium' because among the whole fauna, only a few species will be used. Well-established examples of bacterial consortia are the six and nine species 'Marsh' consortia to model dental plaque (Sissons, 1997; Brown et al., 2019). Both microcosms and consortia can be classified as open (continuous renovation of nutrients, removal of metabolic by-products and aerial exchanges allowed) or closed (bacteria grow on a limited supply of nutrients) (Lebeaux et al., 2013). Open models are sometimes referred to as 'dynamic models' : this definition is widespread in microbiological studies [e.g., in studies using CDC biofilm reactor (Bilal et al., 2019)]. Yet, despite having a continuous medium flow, open bioreactors operate in a stationary state. Therefore, here we will refer to such systems as 'open' and will use the term 'dynamic' for the transient and unstable interactions between microorganisms that will ultimately lead to a new steady-state, different from the initial conditions of the system. The culture conditions deeply affect the response of bacteria to external stimuli, including the effect of antibiotics. The challenge is to produce realistic tools for the study of bacterial interactions and drug discovery. These tools should provide not the complete physiological situation, but the key features relevant for each aim. There is not "the ideal" in vitro model of lung microbiota, as it is strictly dependent on the feature to be tested. In antibiotic resistance studies, e.g., the 3D-matrix is relevant for permeability studies (Pacheco et al., 2019) but also to allow the formation of self-protecting clusters of bacteria (Melaugh et al., 2016). We propose a bottom-up approach in recapitulating the physiological complexity of the microbial niches within in vitro models. This approach implies to deconstruct in pieces the complex physiological situation by employing different tools, such as $3 \mathrm{D}$ models, the in vitro cultures of more than one bacterial species. Mathematical and ecological models complete the picture, by rendering the competing effects of the co-presence of different species.

\section{Modeling the 3D-Microenvironment: in vitro Studies of Biofilm-Embedded Bacteria}

Biofilm is the most common form of life of bacteria on Earth: it represents one of the most non-treatable and recalcitrant forms of infections when considering human health. As an example, 


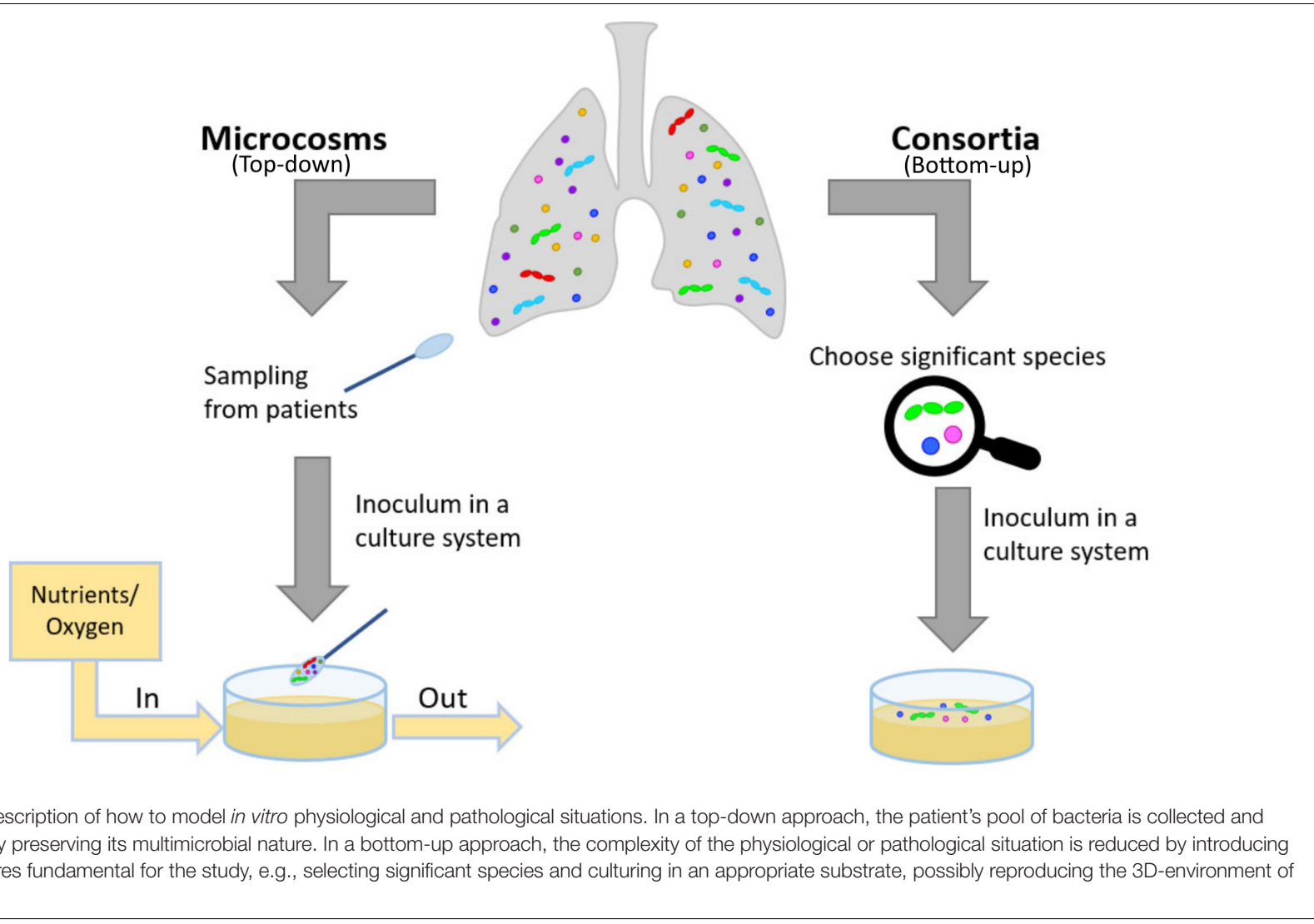

$P$. aeruginosa, that is associated with clinical decline and severe outcomes both in cystic fibrosis and in bronchiectasis, is a biofilm-forming bacterium. The same strain is often involved in chronic wounds, together with Staphylococcus aureus and Clostridium perfringens (Woods et al., 2012; Bertesteanu et al., 2014). Experiences in the literature show resistance of these bacteria to eradication. The inefficacy of the treatment is often believed to be due to established antibiotic-resistant biofilms (Moreau-Marquis et al., 2008). The study of infections, in some cases, reflects a limited perspective, mainly analyzing the behavior of a few well-characterized, pure laboratory bacterial strains. The strategies employed to reproduce in vitro biofilms are examples of 3D-models for bacterial cultures. Pharmacodynamic parameters, as well as culturing devices and analytical methods, will be presented and discussed.

The main classical parameters (Macià et al., 2014), specifically used for planktonic bacteria, are still adopted to analyze the effect of different compounds on biofilm, namely the Minimal Inhibitory Concentration (MIC) and the Minimal Bactericidal Concentration (MBC) (Table 1). Minimal Biofilm Inhibitory Concentration (MBIC) and Biofilm Bactericidal Concentration $(\mathrm{BBC})$ are indeed the two parameters that parallel MIC and $\mathrm{MBC}$ but specifically accounting biofilm. Two further parameters have been harnessed to analyze biofilm responses to external compounds: Biofilm Preventing Concentration (BPC) and Minimal Biofilm Eradication Concentration (MBEC) (Table 1). $\mathrm{BPC}$ refers to the preventive effect of an antibiotic in biofilm formation. Therefore, bacteria are seeded together with the compound under analysis and biofilm growth is monitored (Fernández-Olmos et al., 2012). Nevertheless, MBIC and BPC are reported as the lowest concentration of drug that resulted in an $\mathrm{OD}_{650} \mathrm{~nm}$ difference of $\leq 10 \%$ of the mean of two positive control well readings. Contrarily to BPC, the three parameters MBIC, BBC and MBEC are analyzed on biofilms already formed, subsequently challenged with the drug. MBEC represents the lowest concentration of an antibiotic that prevents visible growth in the recovery medium used to collect biofilm cells. These parameters are useful to compare results among different laboratories, but international guidelines on biofilm are missing, unlike for planktonic cultures (Clinical \& Laboratory Standards Institutes [CLSI], 2019). Examples of reproducibility across different laboratories are available (Parker et al., 2014) but a general lack of standards in anti-biofilm compounds testing is evident.

Aside from the different parameters that can be tested, a panel of experimental setups can be deployed to investigate biofilm-embedded bacteria (Table 2). These culturing devices are in general divided into closed and open systems, the former being mostly related to microtiter plates, the latter involving dynamic systems underflow. Closed systems are in the vast majority of cases, static, batch cultures that are analyzed either during the experiment or at the endpoint. These systems allow scale-up of the analysis, involving more compounds at different concentrations at a single time, 
thanks to the use of microtiter plates. Furthermore, these systems are inexpensive and allow quick readout of the test. Nevertheless, the main limitations of these approaches involve great variations between wells (therefore, usually, at least four replicates for each condition are tested), incomplete disruption of biofilm upon endpoint analysis and presence of exhausted nutrients in the well until the end of the test.

Three main supports have been harnessed to study biofilmforming bacteria in closed systems: apart from plain 96-well tissue culture plates (O’Toole and Kolter, 1998; Stoodley et al., 2002; Ren et al., 2014; Pallavicini et al., 2017), Calgary Biofilm Device

TABLE 1 | Pharmacodynamic parameters employed to analyze the effect of antimicrobial substances, on both planktonic tests and tests accounting biofilm

\begin{tabular}{|c|c|c|c|}
\hline Effect & Acronymous & Definition & Mode of growth \\
\hline \multirow[t]{3}{*}{ Inhibitory effect } & $\mathrm{MIC}$ & $\begin{array}{l}\text { The lowest concentration of an antibiotic that inhibits the visible growth of a planktonic } \\
\text { culture after overnight incubation }\end{array}$ & Planktonic \\
\hline & $\mathrm{MBIC}$ & $\begin{array}{l}\text { The lowest concentration of an antimicrobial substance at which there is no } \\
\text { time-dependent increase in the mean number of biofilm viable cells when an early } \\
\text { exposure time is compared with later exposure time }\left(\mathrm{OD}_{650} \mathrm{~nm} \text { difference of } \leq 10 \% \text { of }\right. \\
\text { the mean of two positive control well readings) }\end{array}$ & Biofilm \\
\hline & $\mathrm{BPC}$ & $\begin{array}{l}\text { The lowest concentration of an antimicrobial substance at which there is no } \\
\text { time-dependent increase in the mean number of biofilm viable cells when bacterial } \\
\text { inoculation and antibiotic exposure occur simultaneously }\left(O D_{650} \mathrm{~nm} \text { difference }\right. \\
\text { of } \leq 10 \% \text { of the mean of two positive control well readings) }\end{array}$ & Biofilm \\
\hline \multirow[t]{3}{*}{ Bactericidal effect } & $\mathrm{MBC}$ & $\begin{array}{l}\text { The lowest concentration of an antibiotic able to produce a } 99.9 \% \text { CFUs reduction of } \\
\text { the initial inoculum of a planktonic culture }\end{array}$ & Planktonic \\
\hline & MBEC & $\begin{array}{l}\text { The lowest concentration of antimicrobial agent that prevents visible growth in the } \\
\text { recovery medium used to collect biofilm cells }\end{array}$ & Biofilm \\
\hline & $\mathrm{BBC}$ & $\begin{array}{l}\text { The lowest concentration of antimicrobial agent that killed } 99.9 \% \text { of the cells recovered } \\
\text { from a biofilm culture compared to growth control }\end{array}$ & Biofilm \\
\hline
\end{tabular}

The Table was reformulated from reference 4 (Copyright Sep 11, 2020) with permission from Elsevier (licenses 4905821434139$)$. CFU (Colony Forming Units).

TABLE 2 | Schematic overview of the strategies available to study biofilm communities.

\begin{tabular}{|c|c|c|c|c|c|c|}
\hline Type & Main Features & Advantages & Drawbacks & Example systems & Evaluated aspects & Study \\
\hline \multirow[t]{2}{*}{ Closed } & $\begin{array}{l}\text { Static cultures. } \\
\text { Realized within } \\
\text { batches and } \\
\text { microtiter plates }\end{array}$ & $\begin{array}{l}\text { Low price. Possible } \\
\text { scale-up of the } \\
\text { analysis High } \\
\text { throughput }\end{array}$ & $\begin{array}{l}\text { Low adherence to } \\
\text { in vivo situations High } \\
\text { variance Exhaust } \\
\text { medium hard to be } \\
\text { eliminated. } \\
\text { Incomplete disruption } \\
\text { of the biofilm }\end{array}$ & $\begin{array}{l}\text { Calgary Biofilm } \\
\text { Device }\end{array}$ & $\begin{array}{l}\text { Growth and shedding } \\
\text { of biofilm on a bump, } \\
\text { immersed in a } \\
\text { bacterial suspension }\end{array}$ & $\begin{array}{l}\text { Harrison et al., 2010; } \\
\text { Chavant et al., } 2007\end{array}$ \\
\hline & & & & BioFilm Ring Test ${ }^{\mathrm{TM}}$ & $\begin{array}{l}\text { Early biofilm } \\
\text { formation is } \\
\text { quantified analyzing } \\
\text { the precipitation } \\
\text { kinetics of a } \\
\text { paramagnetic bead } \\
\text { through the biofilm } \\
\text { itself }\end{array}$ & Peterson et al., 2015 \\
\hline \multirow[t]{4}{*}{ Open } & $\begin{array}{l}\text { Dynamic cultures. } \\
\text { Strong reliance on } \\
\text { bioreactors and } \\
\text { pump systems }\end{array}$ & $\begin{array}{l}\text { Realistic experimental } \\
\text { conditions } \\
\text { Continuous refresh of } \\
\text { the medium }\end{array}$ & $\begin{array}{l}\text { High complexity Low } \\
\text { throughput } \\
\text { Expensiveness }\end{array}$ & Flow Chambers & $\begin{array}{l}\text { Bacteria behavior in } \\
\text { presence of } \\
\text { physiological-like } \\
\text { stimuli }\end{array}$ & $\begin{array}{l}\text { Gómez-Suárez et al., } \\
\text { 2001; Pamp et al., } \\
\text { 2009; Jass et al., } \\
1995\end{array}$ \\
\hline & & & & $\begin{array}{l}\text { Modified Robbins } \\
\text { Device }\end{array}$ & $\begin{array}{l}\text { Biofilm produced on } \\
\text { a given specimen by } \\
\text { a log-phase broth } \\
\text { culture }\end{array}$ & Goeres et al., 2009 \\
\hline & & & & $\begin{array}{l}\text { Drip Flow Biofilm } \\
\text { Reactor }\end{array}$ & $\begin{array}{l}\text { Biofilm produced on } \\
\text { a given specimen } \\
\text { under low fluid shear }\end{array}$ & Donlan et al., 2004 \\
\hline & & & & Bioflux & $\begin{array}{l}\text { Long term } \\
\text { bacteria-bacteria and } \\
\text { bacteria-environment } \\
\text { interactions }\end{array}$ & Lopes et al., 2018 \\
\hline
\end{tabular}


(CBD) and BioFilm Ring Test ${ }^{\mathrm{TM}}$ belong to this category. CBD is composed of a microtiter reservoir plate that perfectly matches a lid with pegs that can be accommodated in the reservoir chamber (Ceri et al., 1999; Harrison et al., 2010). Biofilm grows on the suspended pegs. This system allows contemporary screening of many conditions, reduced volumes and contaminations since little handling is required upon lid transfer. The third set up, BioFilm Ring Test ${ }^{\mathrm{TM}}$, has been instead designed to investigate early biofilm stage formation (Chavant et al., 2007). Paramagnetic beads are co-inoculated upon biofilm seeding and depending on their precipitation or not after an initial incubation, they indicate if the biofilm has formed or not. If the community is starting to build its extracellular matrix, beads are trapped and cannot be therefore attracted toward the bottom of the microtiter plate by a magnet. Instead, if a visible spot appears at the bottom of the well, this indicates that beads can precipitate and therefore the biofilm formation has been hampered.

Concerning open systems, all the devices include a pump, which allows flux of nutrients, and bacterial cells, thus mimicking more realistic conditions, both for environmental and for healthcare-related biofilms. Shear forces are indeed one of the parameters that can induce stress and modify bacterial behavior (Stoodley et al., 2002; Purevdorj et al., 2002; Peterson et al., 2015). Furthermore, fresh medium is provided, while eliminating exhausted one, thus again increasing mimesis of natural environments. Compared to closed systems, open ones guarantee a more complex setup, having as a drawback a reduction in throughput, since not many conditions can be analyzed at the same time. In general, these systems require more expensive settings and maintenance.

Up to now, flow chambers are among the most convenient tools to understand how the embedded bacteria behave in the presence of flux because direct visualization of the samples is possible since the transparent devices can be coupled to microscopes (either optical, fluorescence or confocal) (GómezSuárez et al., 2001; Beyenal et al., 2004; Pamp et al., 2009). Other flow cells that allow parallel testing of different conditions exist, although, in this case, direct imaging is not allowed. These systems are the Modified Robbins Device (Jass et al., 1995) and the Drip Flow Biofilm Reactor (Goeres et al., 2009). Conditions during the experiment can be varied and samples collected thanks to the presence of different valves. Different surfaces can be accommodated within the devices, thus allowing investigation of anti-biofilm surfaces. Imaging is allowed only as an endpoint experimental measure.

The Center for Disease Control Biofilm reactor was named after their inventors (Donlan et al., 2004) and allows testing of up to 24 different coupons in high shear since the system is rotating. Coupons can be easily removed and thus analyzed at different intervals.

Finally, more recently, microfluidic devices have been developed. They can be, to some extent, designed and tailored to each experimental need. These systems are physiologically closer to the conditions that microbial communities may encounter, thus providing a more reliable experimental set up (Drescher et al., 2013; Rusconi et al., 2014). Besides reductions in equipment and reagents, microfluidics allow in-line analysis. Recent advances allowed designing a 96-well plate with connecting microfluidics channels, named BioFlux (Benoit et al., 2010), for throughput analysis.

Different techniques can be employed to analyze biofilmembedded bacteria (Table 3). Viability is one of the first aspects that is analyzed in biofilms. To get quantitative data, the method that implies the count of viable bacteria able to form colonies when re-plated on agar (colony forming units, $\mathrm{CFU}$ ) is still the most adopted yet laborious method. Especially in the multispecies community, recognition of single species ratios is challenging because it requires specific differential and selective agar media, which are not always available and may be expensive (Røder et al., 2016; Lopes et al., 2018). Other quantitative methods rely on metabolic assays in which viable bacteria can transform substrates that may change or turn into a colored product: examples are tetrazolium salts (e.g., XTT or MTT) or resazurin based products (Van den Driessche et al., 2014; Alonso et al., 2017). Other reagents are used to stain biofilms. Crystal violet unspecifically colors extracellular polymeric substance and cell, thus providing broad information on biofilm thickness and growth (Sharma et al., 2008). If instead general information of viable cells is required, staining with LIVE/DEAD BacLightTM Bacterial Viability Kit (Invitrogen) can be performed and visualization under a Confocal Laser Scanning Microscope (CLSM) would also provide the spatial distribution of bacteria. SEM (Golding et al., 2016; Gomes and Mergulhão, 2017; Huang et al., 2020) can provide useful information with a proper sample preparation. Innovative methods employ cryo-SEM and Environmental SEM to avoid dehydration. Approaches that may allow to specifically tag different components of the matrix, while advanced chip microfluidics are leading toward the development of methods with higher throughput (Di Poto et al., 2009; Hansen et al., 2019; Hartmann et al., 2019). Further methods can be applied to differentiate among species, e.g. probing the biofilm with specific Fluorescence In Situ Hybridization (FISH) or with speciesspecific primers with quantitative qPCR (Amann and Fuchs, 2008; Almeida et al., 2011; Azevedo et al., 2011; Ren et al., 2014; Lopes et al., 2018). These approaches are destructive and are carried out as endpoint analysis. An overview of the most used techniques to study biofilm embedded bacteria is reported in Table 3.

Among high-throughput techniques recently developed we can find the so-called -omics technologies. Some of these techniques are genomics, metagenomics, microbiomic, transcriptomics and proteomics, metabolomics (Yates et al., 2009; Sorek and Cossart, 2010; Moree et al., 2012; Krohn-Molt et al., 2013; Liu et al., 2019). These assays can give access to an extensive amount of information, considering bacteria and bacterial genomes, as well as the entire set of transcripts, proteins and metabolites in a target niche (Yates et al., 2009; Sorek and Cossart, 2010; Moree et al., 2012; Krohn-Molt et al., 2013; Liu et al., 2019). Schematic information on some of the most used -omics techniques to study bacterial communities are reported in Table 3. A multi-omics approach is very used in translational 
TABLE 3 | Schematic overview of the strategies available to study biofilm embedded bacteria.

\begin{tabular}{|c|c|c|c|c|c|c|}
\hline Assay & Type & Principle & Features & Advantages & Drawbacks & Study \\
\hline CFU count & Viability & $\begin{array}{l}\text { Diluted bacteria are } \\
\text { plated on agar media } \\
\text { and incubated until } \\
\text { colonies growth; } \\
\text { colonies formed are } \\
\text { counted }\end{array}$ & $\begin{array}{l}\text { Direct quantitative } \\
\text { evaluation of viable } \\
\text { cells }\end{array}$ & $\begin{array}{l}\text { Quick and not } \\
\text { expensive }\end{array}$ & $\begin{array}{l}\text { Difficult to evaluate multispecies } \\
\text { community Specific } \\
\text { differential/selective media are } \\
\text { needed to evaluate different } \\
\text { bacteria The CFU countable } \\
\text { range is relatively narrow, errors } \\
\text { may arise from biofilms (high } \\
\text { cell aggregation) }\end{array}$ & $\begin{array}{l}\text { Røder et al., 2016; } \\
\text { Alonso et al., } 2017\end{array}$ \\
\hline$X T T, M T T$ & $\begin{array}{l}\text { Metabolic } \\
\text { assays }\end{array}$ & $\begin{array}{l}\text { Cells are incubated with } \\
\text { a substrate that is } \\
\text { metabolized by cells in } \\
\text { a colorigenic } \\
\text { compound }\end{array}$ & $\begin{array}{l}\text { Indirect quantitative } \\
\text { evaluation of viable } \\
\text { cells }\end{array}$ & $\begin{array}{l}\text { Mostly used with in } \\
\text { planktonic situation, } \\
\text { quantitative, relatively } \\
\text { expensive }\end{array}$ & $\begin{array}{l}\text { The use of specific compounds } \\
\text { may interact with the substrate } \\
\text { Biofilm embedded bacteria may } \\
\text { have a different metabolic } \\
\text { activity than planktonic bacteria } \\
\text { usually used as standard }\end{array}$ & $\begin{array}{l}\text { Van den Driessche } \\
\text { et al., 2014; } \\
\text { Sharma et al., } 2008\end{array}$ \\
\hline $\begin{array}{l}\text { Crystal } \\
\text { violet }\end{array}$ & $\begin{array}{l}\text { Biofilm } \\
\text { staining }\end{array}$ & $\begin{array}{l}\text { The compound stains } \\
\text { the biofilm making it } \\
\text { visible }\end{array}$ & $\begin{array}{l}\text { Direct measure of } \\
\text { biofilm mass }\end{array}$ & $\begin{array}{l}\text { Provides broad } \\
\text { information on biofilm } \\
\text { thickness and growth }\end{array}$ & $\begin{array}{l}\text { The entire biofilm mass is } \\
\text { stained (extracellular matrix and } \\
\text { cells), no information on cell } \\
\text { viability is given }\end{array}$ & Golding et al., 2016 \\
\hline $\begin{array}{l}\text { Live/dead } \\
\text { staining }\end{array}$ & $\begin{array}{l}\text { Biofilm } \\
\text { staining }\end{array}$ & $\begin{array}{l}\text { The compound } \\
\text { differentially stains cells } \\
\text { based on the integrity } \\
\text { of the membrane }\end{array}$ & $\begin{array}{l}\text { Direct quantitative } \\
\text { measure of viable } \\
\text { cells }\end{array}$ & $\begin{array}{l}\text { Mostly used in } \\
\text { planktonic situation, } \\
\text { may provide the spatial } \\
\text { distribution of bacteria } \\
\text { in a biofilm }\end{array}$ & $\begin{array}{l}\text { High-throughput quantification } \\
\text { of biofilm viability may be } \\
\text { difficult The use of CLSM is } \\
\text { needed }\end{array}$ & $\begin{array}{l}\text { Gomes and } \\
\text { Mergulhão, } 2017\end{array}$ \\
\hline $\mathrm{FISH}$ & $\begin{array}{l}\text { Species } \\
\text { differentiation }\end{array}$ & $\begin{array}{l}\text { Species specific } \\
\text { fluorescent probes } \\
\text { hybridize with bacterial } \\
\text { oligonucleotides } \\
\text { making bacteria visible }\end{array}$ & $\begin{array}{l}\text { Direct qualitative } \\
\text { visualization of } \\
\text { different strains }\end{array}$ & $\begin{array}{l}\text { The use of a different } \\
\text { probes specifically } \\
\text { distinguishes among } \\
\text { bacteria }\end{array}$ & $\begin{array}{l}\text { If the probe target is low, the } \\
\text { signal may be not detectable } \\
\text { against the background }\end{array}$ & $\begin{array}{l}\text { Parker et al., 2014; } \\
\text { Røder et al., 2016; } \\
\text { Hansen et al., } \\
\text { 2019; Hartmann } \\
\text { et al., 2019; } \\
\text { Almeida et al., } 2011\end{array}$ \\
\hline qPCR & $\begin{array}{l}\text { Species } \\
\text { differentiation }\end{array}$ & $\begin{array}{l}\text { PCR amplification of a } \\
\text { target release } \\
\text { fluorescence } \\
\text { proportional to the initial } \\
\text { bacterial load }\end{array}$ & $\begin{array}{l}\text { Direct quantitative } \\
\text { or semi-quantitative } \\
\text { visualization of } \\
\text { bacteria }\end{array}$ & $\begin{array}{l}\text { The use of a different } \\
\text { probes specifically } \\
\text { distinguishes among } \\
\text { bacteria }\end{array}$ & $\begin{array}{l}\text { It does not distinguish among } \\
\text { viable and non-viable cells }\end{array}$ & $\begin{array}{l}\text { Ceri et al., 1999; } \\
\text { Røder et al., } 2016\end{array}$ \\
\hline Microbiome & $\begin{array}{l}\text { Next } \\
\text { generation } \\
\text { sequencing }\end{array}$ & $\begin{array}{l}\text { Next-generation } \\
\text { sequencing target } \\
\text { amplification of } 16 \mathrm{~s} \\
\text { rRNA gene }\end{array}$ & $\begin{array}{l}\text { Direct relative } \\
\text { analysis of } \\
\text { microbial } \\
\text { community }\end{array}$ & $\begin{array}{l}\text { Untargeted and } \\
\text { relatively expensive, } \\
\text { high-throughput }\end{array}$ & $\begin{array}{l}\text { Not quantitative, bacteria } \\
\text { identification to genus }\end{array}$ & $\begin{array}{l}\text { Sorek and Cossart, } \\
2010\end{array}$ \\
\hline $\begin{array}{l}\text { Shotgun } \\
\text { metagenomics }\end{array}$ & $\begin{array}{l}\text { Next } \\
\text { generation } \\
\text { sequencing }\end{array}$ & $\begin{array}{l}\text { Next-generation } \\
\text { sequencing of genes in } \\
\text { all bacteria }\end{array}$ & $\begin{array}{l}\text { Direct relative } \\
\text { analysis of } \\
\text { microbial } \\
\text { community and } \\
\text { bacterial features }\end{array}$ & $\begin{array}{l}\text { Untargeted, acquisition } \\
\text { of all the genetic } \\
\text { information in the } \\
\text { bacteria }\end{array}$ & $\begin{array}{l}\text { Very expensive High } \\
\text { bioinformatic expertise needed } \\
\text { for data-analysis }\end{array}$ & $\begin{array}{l}\text { Amann and Fuchs, } \\
\text { 2008; Sorek and } \\
\text { Cossart, } 2010\end{array}$ \\
\hline $\begin{array}{l}\text { Metatran } \\
\text { scriptomics }\end{array}$ & $\begin{array}{l}\text { Next } \\
\text { generation } \\
\text { sequencing }\end{array}$ & $\begin{array}{l}\text { Next-generation } \\
\text { sequencing approach } \\
\text { to study gene } \\
\text { expression of profile of } \\
\text { the whole bacterial } \\
\text { community }\end{array}$ & $\begin{array}{l}\text { Direct relative } \\
\text { analysis of bacterial } \\
\text { gene expression }\end{array}$ & $\begin{array}{l}\text { Untargeted, acquisition } \\
\text { of all the gene } \\
\text { expression of } \\
\text { sequenced bacterial } \\
\text { community }\end{array}$ & $\begin{array}{l}\text { Very expensive High } \\
\text { bioinformatic expertise needed } \\
\text { for data-analysis }\end{array}$ & $\begin{array}{l}\text { Azevedo et al., } \\
\text { 2011; Liu et al., } \\
\text { 2019; Sorek and } \\
\text { Cossart, } 2010\end{array}$ \\
\hline SEM & $\begin{array}{l}\text { Morphological } \\
\text { observation }\end{array}$ & $\begin{array}{l}\text { Scanning electron } \\
\text { microscopy } \\
\text { observations. Samples } \\
\text { fixed and gold } \\
\text { sputtered. Innovative } \\
\text { preparative steps of the } \\
\text { sample and alternatives } \\
\text { to gold sputtering. } \\
\text { Possible wet-SEM and } \\
\text { cryo-SEM to avoid } \\
\text { dehydration steps. }\end{array}$ & $\begin{array}{l}\text { Morphological and } \\
\text { spatial analysis of } \\
\text { both the } \\
\text { three-dimensional } \\
\text { matrix and the } \\
\text { embedded bacteria }\end{array}$ & $\begin{array}{l}\text { High resolution and } \\
\text { magnification. High } \\
\text { depth of field Suitable } \\
\text { for analyses on } \\
\text { heterogeneous } \\
\text { surfaces Possibility to } \\
\text { identify the type (in } \\
\text { some case the genus) } \\
\text { of the microbe }\end{array}$ & $\begin{array}{l}\text { No viability informations The } \\
\text { use of fluorochromes is not } \\
\text { allowed The output of the } \\
\text { analysis is strictly dependent on } \\
\text { not-obvious preparative steps } \\
\text { Low sensitivity unless } \\
\text { concentrated samples used }\end{array}$ & $\begin{array}{l}\text { Golding et al., } \\
\text { 2016; Gomes and } \\
\text { Mergulhão, 2017; } \\
\text { Huang et al., } 2020\end{array}$ \\
\hline
\end{tabular}

CFU, colony forming units; CLSM, Confocal Laser Scanning Microscope; FISH, fluorescence in situ hybridization; qPCR, Real time PCR; SEM, Scanning Electron Microscopy. 


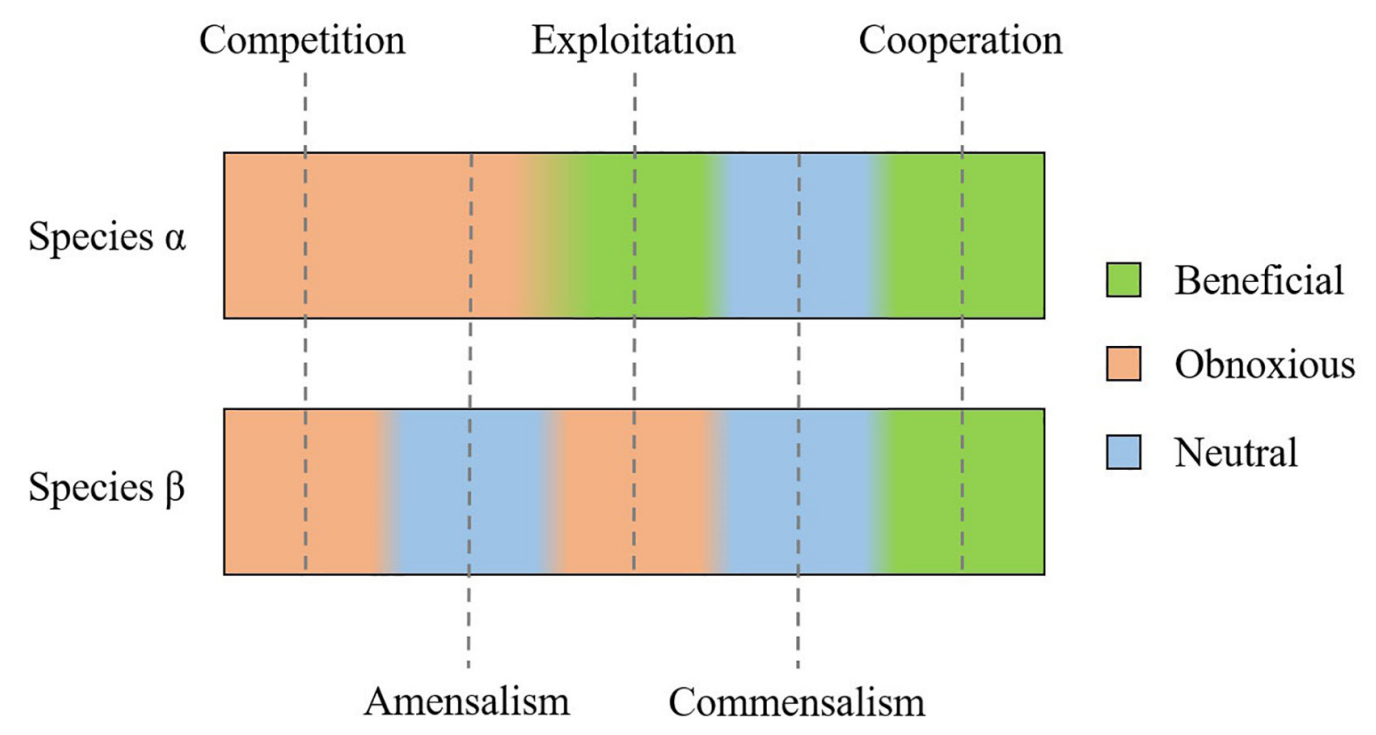

FIGURE 3 | Possible interaction between two bacterial species ( $\alpha$ and $\beta$ ): competition and cooperation are respectively obnoxious or beneficial for both species. Exploitation is beneficial for species $\alpha$, at the expense of species $\beta$; whereas amensalism and commensalism do not affect species $\beta$, but are respectively obnoxious or beneficial to species $\alpha$.

research in the study of the interaction between bacterial niches and host response in human diseases (Hasin et al., 2017).

\section{Modeling the Interactions of Different Bacterial Strains: Co-cultures}

Bacteria are usually considered as single-cell organisms and their ability to interact and form monospecies biofilms is quite often overlooked. The use of in vitro co-culture, a family of laboratory techniques that aim at growing two or more different cell types on the same support, is the current strategy to study multistrain interactions. The general purpose of coculture is to recapitulate in vitro key communication and interaction mechanisms, which might intervene in vivo among the target cell types (Bogdanowicz and Lu, 2013), thus enabling the uncovering of crucial phenomena to design new therapies. Three macro-groups of co-cultures are distinguished based on the kind of cultured cells. Firstly, co-cultures of eukaryotic cells are realized by growing different cell types to either study physiological interactive processes (Bam et al., 2015; Jia et al., 2017; Yin et al., 2017) or develop a functional construct to be used in tissue engineering approaches (Vuornos et al., 2019). Similarly, co-cultures of prokaryotic cells have also been realized, in which various bacterial strains are cultured for many objectives, spacing from the study of interspecies quorum-sensing occurrences (An et al., 2006) to the industrialized production of chemicals (Jones and Wang, 2018). Hybrid co-cultures have also been proposed, in which both eukaryotic and prokaryotic cells are cultured, in the attempt to understand physiological symbiosis relations (Haller et al., 2000), or pathological effects on tissues after the settlement of an infectious phenomenon (Kim et al., 2010).

Co-cultures of prokaryotic cells are crucial for the development of new therapies against threatening diseases that are characterized by the presence of complex infectious microbiomes (e.g., cystic fibrosis, bronchiectasis, tuberculosis). However, the realization of fully functional and effective models is still challenging due to both the complexity of the in vivo microbiome itself, and the compelling boundary conditions stated by the host organism. Moreover, due to the novelty of the topic, a consensus on one platform for the realization of bacterial co-cultures does not exist yet. As a result, in our opinion, different studies relate to different protocols to be developed in a time-consuming quest of the appropriate experimental conditions. Moreover, in consequence, the results are difficult to compare and the whole picture to be reconstructed is rendered in parts that, in some cases, are difficult to match. Up to now, it is not possible to culture the whole microbiota and this challenge is far to be met.

\section{MATHEMATICAL AND ECOLOGICAL MODELS FOR MICROBIAL CO-CULTURES}

Mathematical models have characterized single-strain bacterial genetic evolution (Hindré et al., 2012) and antibiotic resistance (Greulich et al., 2015). Once validated, such models allow us to explore many different scenarios in a cost-effective way (Hindré et al., 2012; Allen and Waclaw, 2016). This possibility becomes of interest when modeling polymicrobial consortia facing the fact that bacteria do not live in monocultures in nature. In mixed communities, the most common natural ecosystems, each and every species optimized for different functions (Kneitel and Chase, 2004), and the interaction between different species sharing metabolic resources, defined as cross-feeding (Estrela et al., 2012; Coyte et al., 2015), has been modeled. Ecological 
theories in the framework of microbial consortia engineering aimed at designing efficient co-cultures for biofuel production or enhanced mineral recovery (Bernstein and Carlson, 2012). These theories have been applied also to human microbiota and polymicrobial infections (Costello et al., 2012; de Vos et al., 2017). In particular, it is possible to distinguish five different ecological interactions, when cross-feeding is involved (Figure 3; Coyte et al., 2015; Bernstein and Carlson, 2012; Faust and Raes, 2012):

- competition for space and resources;

- amensalism: one organism is inhibited or destroyed while the other organism remains unaffected;

- exploitation: one organism takes advantage of the other for resources scavenging and metabolism;

- commensalism: neither of the bacteria benefits from the other or provokes any harm;

- and cooperation: both the organisms benefit from the relation.

Mathematical models aim to relate the physical characteristics of the studied system and its dynamic evolution starting from the initial conditions until the system reaches an equilibrium. In case there are two bacterial strains and they coexist at the equilibrium, a bistability condition is reached (El Hajji et al., 2009; Wang and Wu, 2011; Assaneo et al., 2013). Considering the basic example of a chemostat, it is possible to model it with a system of five equations that describe the interaction between the bacteria and their nutrient support and consumption (Speirs et al., 1996). The outputs of the model are the variation in time of the bacterial population density and the nutrient concentration. The system of equations relates such variation with the system working conditions (e.g., initial population density of the bacterial species involved, growth rate, nutrient flow and intake) (Speirs et al., 1996). In this case, however, the relation between stability condition and model parameters is not straightforward, for the high the number of parameters required to solve the system of equations. To simplify it, it is possible to use the Lodka-Volterra equations that were initially designed to describe just the preypredator competitive interaction (Lotka, 1922; Volterra, 1928), but they were generalized to all kinds of ecological interactions (May, 1973; Solé and Bascompte, 2012). This model consists of fewer equations than the physical model and a limited number of parameters that retain a physical interpretation of the model characteristics (Vet et al., 2018). Indeed, the Lodka-Volterra model will consist of as many equations as many are the species involved in the chemostat (e.g., two competing species will result in a model with two equations). Thanks to this simplification, it is easier to explore the relation between the initial conditions and the possible multiple species coexistence at the equilibrium (Vet et al., 2018). The model relies on some simplifying hypothesis: it ignores the mechanisms of interaction (like predator preferences) and it is based on the additivity assumption (Momeni et al., 2017). The latter assumes that pairwise interactions are sufficient to describe microbial community dynamics: the fitness of the polymicrobial system results from the sum of the fitness of each individual species, given by the interaction of the aforementioned species and the other interacting species (Momeni et al., 2017).
Since it has been recently proven that the additivity assumption may fail, due to the complex non-linear interactions present in microbial communities (Dormann and Roxburgh, 2005; Momeni et al., 2017), it is possible to use higher-order models (Bairey et al., 2016) or models closer to the physical systems they want to describe (Vet et al., 2018), but at the expense of model simplicity.

Considering a relevant case of polymicrobial infections as Cystic Fibrosis, clinical data has been gathered regarding the microbial populations present under different conditions (age, use of antibiotics) (Klepac-Ceraj et al., 2010; Sherrard et al., 2019). In the near future, these databases could be exploited to validate mathematical models able to predict the development of infections in CF patients, knowing the patient history and, therefore, to choose the best treatment for each clinical case.

\section{FOCUS ON IN VITRO MODELS FOR CYSTIC FIBROSIS}

Cystic fibrosis (CF) is one notable example of how the absence of well-established laboratory protocols for the realization of bacterial co-cultures drives researchers to choose and optimize different methods and culture conditions that are case-dependent systems, which challenges the comparison of data among different laboratories. One of the most pernicious aspects of this disease resides in the high number of species composing the infectious microbiome (Huang and LiPuma, 2016), resulting in a dynamic evolution of the chronic pulmonary infections throughout the life of the patients. Such behavior is one of the main factors causing the inefficiency of a classical antibiotic therapy in completely eradicating lungs-resident pathogens. Various in vivo models have been developed to test antibiotics efficacy: an essential requirement for such a model is the progression from a spontaneous bacterial infection to a chronic stage associated with biofilm formation (Lebeaux et al., 2013). In vitro models, on the other hand, can be useful to elucidate different aspects, such as the competitive effects of the different species on their viability and the modification of genic expression due to gain resistance to antibiotic treatments. The factors promoting the coexistence of different pathogens, such as phenotype modification, and their adaptive evolution to accommodate different species are also complex aspects that need to be understood and controlled. Most of the studies are conducted by dual cultures, with $S$. aureus and $P$. aeruginosa.

It is well known that $S$. aureus is the main colonizer of lung mucosa from the childhood of the cystic fibrosis patients, until the establishment of $P$. aeruginosa colonies, which tend to prevail in $S$. aureus. Despite the majority of in vitro models assuming $P$. aeruginosa to carry on complete eradication of $S$. aureus, it is uncommon to isolate both bacterial species from Cystic Fibrosis-infected lungs. In an in vitro model, it has been demonstrated that the culture in dual-species biofilm led to a consistent decrease of $S$. aureus relative abundance without achieving its complete eradication (Woods et al., 2018). This study exploits both a relatively simple closed multiwell model and a microfluidic system based on the culture of the strains on silicon tubes with a continuous circulation of fresh medium (Woods 
et al., 2018). The same model was previously used by the same authors to study the effect of signaling molecules on the genetic expression of $P$. aeruginosa monocultures (Davies and Marques, 2009; Marques et al., 2014). In the open model, bacteria grow at the liquid/solid interface: this configuration is gradually adding complexity concerning the basic multiwell closed model, but it is still far from the lung environment.

Two different co-culture systems were able to provide a deeper and more specific model for the early interaction of the two strains. It was supposed that $P$. aeruginosa genes, responsible to produce substances inducing the elimination of $S$. aureus, were downregulated when grown in dual-species biofilm. Both single and dual-species biofilms of $S$. aureus and $P$. aeruginosa were grown. To test this hypothesis, two experimental conditions were considered. In the first one $P$. aeruginosa was introduced at a specific proportion, that could mimic the in vivo situation in which a small amount of $P$. aeruginosa encounters a bigger and well-established amount of $S$. aureus, after the development of $S$. aureus biofilm. In the second, bacterial biofilms were co-cultured since the beginning of the experiment. While the previous example investigated the responses produced by the co-culture of bacteria in the mid-term (days), another research studied the reactions triggered at a genetic level during a short period (hours) of co-culture. In particular, various genomic analyses revealed how the competition for resources drives the first responses. The encounter of the two pathogens stimulated the up-regulation of genes related to the optimization of all those factors functional to the adaptation of metabolism, to excel in the competition for resources (Tognon et al., 2019). Pure cultures of $P$. aeruginosa and $S$. aureus were thus produced, and co-cultures were prepared by mixing the previously formed monocultures. Genomic analysis to evaluate changes in genic expressions of both organisms subsequently performed via RNA extraction, RNA-seq assays, and quantitative. Real Time-PCR (qPCR) (Tognon et al., 2019). In this case, a closed multiwell system was implemented, and single and co-cultures were seeded on solid agar plates enriched with nutrients and ions to sustain bacterial growth and mimic physiological conditions. The medium was tailored in previous studies to ensure a similar growth rate of both species (Tognon et al., 2017). Despite being elementary, the growth of the biofilms at the solid/air interface reproduces the pulmonary environment more than a microfluidic system.

The realization of in vitro co-cultures recently also played a key role in studying the causes of several evolutive changes observed in $P$. aeruginosa adaptation to the CF lung environment, like downregulation of lipopolysaccharide (LPS) and quorum sensing (QS) factors. P. aeruginosa might undergo two highly represented mutations (Tognon et al., 2017). The first one (WSPlevel mutation, negatively correlated with $S$. aureus survival rates) was supposed to be caused by the culture condition (growth in a low oxygen environment) since it was present in both mono-cultured and co-cultured bacteria. The second mutation (a mutation at LPS level, increasing $P$. aeruginosa antibiotic resistance) appeared instead only in co-cultured $P$. aeruginosa, thus it has been thought to be an adaptive response to the presence of $S$. aureus. Such an experiment has been performed

TABLE 4 | Main features of recent experiments designed to explore bacterium-bacterium interactions in the case of cystic fibrosis.

\begin{tabular}{|c|c|c|c|c|c|c|}
\hline Model type & Approach & Species & Culture Conditions & Physical Parameters & Aim & Study \\
\hline $\begin{array}{l}\text { CL (multiwell) } \\
\text { and OP } \\
\text { (continuous } \\
\text { flow in silicon } \\
\text { tubes } \\
\text { bioreactor) }\end{array}$ & Consortium & $\begin{array}{l}P . \text { aeruginosa } \\
\text { S. aureus }(1: 250)\end{array}$ & $\begin{array}{l}\text { Medium: BHI 20\% (CL), BHI } \\
\text { 10\% (OP) Seeding: } 7 \times 10^{7} \\
\text { cells/ml (S. aureus) (OP and CL) }\end{array}$ & $\begin{array}{l}\mathrm{T}: 37^{\circ} \mathrm{C}(\mathrm{CL}), 22^{\circ} \mathrm{C}(\mathrm{OP}) \\
\text { Replenishing rate }(\mathrm{CL}): 12 \mathrm{~h} \\
\text { Medium flow (OP): } 10.8 \mathrm{ml} / \mathrm{h} \\
\text { Duration (S. aureus): } 5 \text { days } \\
\text { Duration (coculture): } 14 \text { days } \\
\text { Sampling Rate: } 24 \mathrm{~h}\end{array}$ & $\begin{array}{l}\text { Dynamic } \\
\text { competition }\end{array}$ & $\begin{array}{l}\text { Woods et al., } \\
2018\end{array}$ \\
\hline $\begin{array}{l}\text { CL: multiwell, } \\
\text { solid agar } \\
\text { medium }\end{array}$ & Consortium & $\begin{array}{l}\text { P. aeruginosa } \\
\text { S. aureus }(1: 1)\end{array}$ & $\begin{array}{l}\text { Medium: (tailored) M14 } \\
\text { Seeding: } 10^{8} \mathrm{CFU} / \mathrm{ml}\end{array}$ & $\begin{array}{l}\mathrm{T}: 37^{\circ} \mathrm{C} \text { Duration: } 3 \mathrm{~h} \text { (mono } \\
\text { and cocultures) }\end{array}$ & $\begin{array}{l}\text { Dynamic } \\
\text { competition } \\
\text { Genetic expression }\end{array}$ & $\begin{array}{l}\text { Tognon et al., } \\
2019\end{array}$ \\
\hline $\begin{array}{l}\text { CL: multiwell, } \\
\text { liquid medium }\end{array}$ & Consortium & $\begin{array}{l}\text { P. aeruginosa } \\
\text { S. aureus }(1: 100 \\
\text { and } 1: 1000)\end{array}$ & $\begin{array}{l}\text { Medium: (tailored) M14 } \\
\text { Seeding: } 5 \text { ( @\#105 CFU per } \\
\text { well (P. aeruginosa }\end{array}$ & $\begin{array}{l}\mathrm{T}: 37^{\circ} \mathrm{C} \text { Duration: } 15 \text { days } \\
\text { Sampling rate: } 24 \mathrm{~h} .\end{array}$ & $\begin{array}{l}\text { Adaptation to lung } \\
\text { environment }\end{array}$ & $\begin{array}{l}\text { Tognon et al., } \\
2017\end{array}$ \\
\hline $\begin{array}{l}\text { CL: solid agar } \\
\text { medium }\end{array}$ & $\begin{array}{l}\text { In between } \\
\text { consortium and } \\
\text { microcosm }\end{array}$ & $\begin{array}{l}\text { P. aeruginosa } \\
\text { (clinical isolate) } \\
\text { S. aureus (lab } \\
\text { strain) }(1: 1)\end{array}$ & $\begin{array}{l}\text { Medium: LB ( } P \text {. aeruginosa), } \\
\text { TSB }(S . \text { aureus) Seeding: } \\
{[0.5 ; 1] \times 10^{8} \mathrm{CFU} / \mathrm{ml}}\end{array}$ & $\mathrm{T}: 37\left(^{\circ} \mathrm{C}\right.$ Duration: $16 \mathrm{~h}$ & Genetic expression & $\begin{array}{l}\text { Limoli et al., } \\
2017\end{array}$ \\
\hline $\begin{array}{l}\text { CL: multiwell, } \\
\text { liquid }\end{array}$ & Consortium & $\begin{array}{l}P . \text { aeruginosa } \\
\text { S. aureus }\end{array}$ & $\begin{array}{l}\text { Medium: LB (P. aeruginosa), } \\
\text { TSB (S. aureus), MEM + L-Gln } \\
\text { Seeding: } 50 \mu \text { I of } 0.05 \mathrm{OD}_{600} \\
\text { cell suspension (S. aureus), ans } \\
P . \text { aeruginosa supernatant }\end{array}$ & $\begin{array}{l}\mathrm{T}: 37^{\circ} \mathrm{C} \mathrm{CO}_{2}: 5 \% \text { Duration: } \\
30 \mathrm{~h}\end{array}$ & $\begin{array}{l}\text { Antibiotic } \\
\text { resistance }\end{array}$ & $\begin{array}{l}\text { Orazi and } \\
\text { O'Toole, } 2017\end{array}$ \\
\hline $\begin{array}{l}\text { CL: bacteria } \\
\text { cultured onto } \\
\text { epithelial cell } \\
\text { monolayers }\end{array}$ & Microcosm & $\begin{array}{l}\text { P. aeruginosa } \\
\text { (biofilm forming and } \\
\text { non-forming } \\
\text { strains) + epithelial } \\
\text { cells }\end{array}$ & $\begin{array}{l}\text { Medium: LB Seeding: } 1.0 \\
\text { OD }_{600} P \text {. aeruginosa } \\
\text { suspension diluted up to } 1: 500 \\
\text { and seeded on murine epithelial } \\
\text { cells }\end{array}$ & $\mathrm{T}: 37^{\circ} \mathrm{C}$ Duration: $20 \mathrm{~h}$ & Biofilm formation & $\begin{array}{l}\text { Woodworth } \\
\text { et al., 2008; } \\
\text { Cont et al., } \\
2020\end{array}$ \\
\hline
\end{tabular}

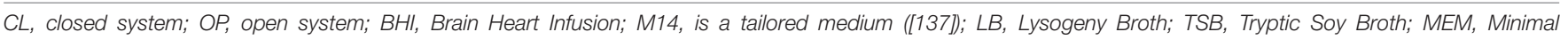
Essential Medium. 
through the establishment of a peculiar protocol, in which $P$. aeruginosa has been evolved for at least 150 generations in liquid close multiwell cultures, both in the presence and absence of $S$. aureus, since interactions between $P$. aeruginosa and $S$. aureus are thought to be crucial in this process of adaptation. Serial dilutions of cellular suspensions were performed to mimic the in vivo situation in which a small amount of $P$. aeruginosa encounters pre-established large colonies of $S$. aureus.

Moreover, an interesting mutation of $P$. aeruginosa might take place in CF patients' lungs, characterized by a switch from the native phenotype toward the so-called "mucoid" phenotype, which owes its name to the overproduction of alginate (Pritt et al., 2007). P. aeruginosa was demonstrated to undergo this phenotypic shift, expressing the mucoid phenotype not only characterized by the up-regulation of genes responsible for alginate production, but also by the down-regulation of genes encoding for virulence factors responsible of killing $S$. aureus (Limoli et al., 2017). Their protocol relied on the "agar-plate cross streak assay" (Balouiri et al., 2016). More in detail, P. aeruginosa isolated from mono-infected and co-infected patients was crossstreaked to a laboratory strain of $S$. aureus. In the same way, $S$. aureus clinical isolation was cross-streaked to a laboratory strain of $P$. aeruginosa (Limoli et al., 2017). This model, therefore, is in between the consortium and microcosm classification, as it sources parts of the bacteria from patients and partially from laboratory culture.

Another field taking advantage of in vitro co-cultures is the research against antibiotics resistance. Clinical data supported the hypothesis that the exposure of $S$. aureus to $P$. aeruginosa by-product leads to a drastic decrease in vancomycin (frontline antibiotic to treat $S$. aureus infections) efficiency against $S$. aureus (Filkins et al., 2015). This phenomenon was examined and it was found out that in the presence of the $P$. aeruginosa supernatant, vancomycin activity was reduced, and more colonies were detected whether $S$. aureus was cultured in planktonic or as biofilms. Given that $P$. aeruginosa tends to over-compete $S$. aureus while co-cultured (both in vivo and in vitro models), co-cultures were prepared in a peculiar way called "biofilm disruption assay" (Orazi and O'Toole, 2017). This procedure relied on the preparation of $S$. aureus monocultures. Then the biofilm produced by $S$. aureus pure cultures was mechanically disrupted, and $P$. aeruginosa supernatant was joined. This method compared to the Minimal Bactericidal Concentration (MBC) assay for planktonic cultures and as an alternative to the other methods to assess antibiotic resistance in biofilms.

Eventually, considering the role played by biofilm formation, the ability of $P$. aeruginosa to form biofilm was studied. This ability was investigated through scanning electron microscopy and confocal microscopy of different $P$. aeruginosa strains on an airway epithelial cell (Woodworth et al., 2008). Biofilmforming strains were able to produce viable biofilms on the surface of airway epithelial cell monolayer. Further, $P$. aeruginosa and $V$. Cholerae were cultured on a monolayer of endothelial cells to assess the mechanobiological effect on the cells (Cont et al., 2020). In these cases, the co-culture is represented by the simultaneous culture of prokaryotic and eukaryotic cells. Despite being far from the physiological environment, such systems can be considered a microcosm for the complexity introduced by this type of co-culture.

It is glaring how the realization of a reliable in vitro model represents nowadays a crucial point for better understanding, and, consequently, try to solve as many criticalities as possible of such a polyhedral disease. However, comparing the experiments considered, it is possible to notice a remarkable heterogeneity under various points of view (e.g., duration of cultures, culture medium, and seeding ratios) (Table 4). Moreover, most of the experiments refer to planktonic cultures, without considering the case of bacteria grown inside some three-dimensional matrix mimicking the pulmonary CF mucus, which is known to be crucial in influencing bacterial behaviors. Regrettably, the realization of both a standard procedure and support, allowing the realization of co-cultures, still represents a big challenge. This reason is pushing scientists to realize culture systems tailored for the experimental purpose.

\section{CONCLUSIVE REMARKS}

The study of the biological features of polymicrobial infections needs to be considered to develop effective antimicrobial strategies useful to treat complex and chronic diseases like CF and bronchiectasis. The available in vitro testing methods provide the state-of-the-art although they were not developed to study the crosstalk among different bacteria and the effect of the three-dimensional environment. They represent important but limited examples available up-to-now: two-species cultures and biofilms as unique examples of polymicrobial cultures and 3Denvironments, respectively. New developments in co-cultures and the study of in vitro bacterial three-dimensional substrates are needed to overcome the frontier for the production of realistic tools to be employed in the study of bacterial interactions and drug discovery and to switch to the reproduction of $3 \mathrm{D}$ environments and polymicrobial cultures. Within this scenario, we envision the need for in vitro methods that could impact on diverse applicative sectors.

\section{AUTHOR CONTRIBUTIONS}

MO and LZ worked on the draft of the document and revised the manuscript with the help of GG. LZ organized the bibliography. FB and SVU wrote the first draft of some sections. PP organized and focussed the contributions and coordinated the revision and the answers to the reviewers. PP and LV designed the content and the structure of the review and critically revised the manuscript in all stages. All authors contributed to the final manuscript revision, read and approved the submitted version.

\section{FUNDING}

The research was also supported by a grant of the Italian Ministry of Education, University and Research (MIUR) to the Department of Molecular Medicine at the University of Pavia under the initiative "Dipartimenti di Eccellenza (2018-2022)." 


\section{ACKNOWLEDGMENTS}

Authors are grateful to Ing. Anna Ziccarelli, since part of this manuscript stemmed from her master

\section{REFERENCES}

Allen, R., and Waclaw, B. (2016). Antibiotic resistance: a physicist's view. Phys. Biol. 13:045001. doi: 10.1088/1478-3975/13/4/045001

Almeida, C., Azevedo, N. F., Santos, S., Keevil, C. W., and Vieira, M. J. (2011). Discriminating multi-species populations in biofilms with peptide nucleic acid fluorescence in situ hybridization (PNA FISH). PLoS One 6:e14786. doi: 10. 1371/journal.pone.0014786

Alonso, B., Cruces, R., Pérez, A., Sánchez-Carrillo, C., and Guembe, M. (2017). Comparison of the XTT and resazurin assays for quantification of the metabolic activity of Staphylococcus aureus biofilm. J. Microbiol. Methods 139, 135-137. doi: 10.1016/j.mimet.2017.06.004

Amann, R., and Fuchs, B. M. (2008). Single-cell identification in microbial communities by improved fluorescence in situ hybridization techniques. Nat. Rev. Microbiol. 6, 339-348. doi: 10.1038/nrmicro1888

Amati, F., Franceschi, E., Gramegna, A., Chalmers, J. D., and Aliberti, S. (2017). Investigating the etiology of bronchiectasis: you do not find what you do not look for. Respiration 93, 228-229. doi: 10.1159/000455880

Amon, P., and Sanderson, I. (2017). What is the microbiome? Arch. Dis. Child Educ. Pract. Ed. 102, 257-260.

An, D., Danhorn, T., Fuqua, C., and Parsek, M. R. (2006). Quorum sensing and motility mediate interactions between Pseudomonas aeruginosa and Agrobacterium tumefaciens in biofilm cocultures. Proc. Natl. Acad. Sci. U.S.A. 103, 3828-3833. doi: 10.1073/pnas.0511323103

Assaneo, F., Coutinho, R. M., Lin, Y., Mantilla, C., and Lutscher, F. (2013). Dynamics and coexistence in a system with intraguild mutualism. Ecol. Complex. 14, 64-74. doi: 10.1016/j.ecocom.2012.10.004

Azevedo, N. F., Jardim, T., Almeida, C., Cerqueira, L., Almeida, A. J., Rodrigues, F., et al. (2011). Application of flow cytometry for the identification of Staphylococcus epidermidis by peptide nucleic acid fluorescence in situ hybridization (PNA FISH) in blood samples. Antonie Van Leeuwenhoek 100, 463-470. doi: 10.1007/s10482-011-9595-9

Bairey, E., Kelsic, E. D., and Kishony, R. (2016). High-order species interactions shape ecosystem diversity. Nat. Commun. 7:12285.

Balouiri, M., Sadiki, M., and Ibnsouda, S. K. (2016). Methods for in vitro evaluating antimicrobial activity: a review. J. Pharm. Anal. 6, 71-79. doi: 10.1016/j.jpha. 2015.11.005

Bam, R., Khan, S., Ling, W., Randal, S. S., Li, X., Barlogie, B., et al. (2015). Primary myeloma interaction and growth in coculture with healthy donor hematopoietic bone marrow. BMC Cancer 15:864. doi: 10.1186/s12885-0151892-7

Barbieri, N., Herrera, M., Salva, S., Villena, J., and Alvarez, S. (2017). Lactobacillus rhamnosus CRL1505 nasal administration improves recovery of T-cell mediated immunity against pneumococcal infection in malnourished mice. Benef. Microbes 8, 393-405. doi: 10.3920/bm2016.0152

Barbieri, N., Salva, S., Herrera, M., Villena, J., and Alvarez, S. (2019). Nasal priming with Lactobacillus rhamnosus CRL1505 stimulates mononuclear phagocytes of immunocompromised malnourished mice: improvement of respiratory immune response. Probiotics Antimicrob. Proteins 12, 494-504. doi: 10.1007/ s12602-019-09551-8

Barbieri, N., Villena, J., Herrera, M., Salva, S., and Alvarez, S. (2013). Nasally administered Lactobacillus rhamnosus accelerate the recovery of humoral immunity in B lymphocyte-deficient malnourished mice. J. Nutr. 143, 227-235. doi: $10.3945 /$ jn.112.165811

Bassis, C. M., Erb-Downward, J. R., Dickson, R. P., Freeman, C. M., Schmidt, T. M., Young, V. B., et al. (2015). Analysis of the upper respiratory tract microbiotas as the source of the lung and gastric microbiotas in healthy individuals. mBio 6:e00037-15.

Bauer, H., Horowitz, R. E., Levenson, S. M., and Popper, H. (1963). The response of the lymphatic tissue to the microbial flora. Studies on germfree mice. Am. J. Pathol. 42, 471-483. thesis work. PP., LV., GG. and SVU thank Switch to Product 2018 project, funded by Politecnico di Milano, which supported the increase of knowledge in this field.

Benoit, M. R., Conant, C. G., Ionescu-Zanetti, C., Schwartz, M., and Matin, A. (2010). New device for high-throughput viability screening of flow biofilms. Appl. Environ. Microbiol. 76, 4136-4142. doi: 10.1128/aem.03065-09

Bernstein, H. C., and Carlson, R. P. (2012). Microbial consortia engineering for cellular factories: in vitro to in silico systems. Comput. Struct. Biotechnol. J. 3:e201210017. doi: 10.5936/csbj.201210017

Bertesteanu, S., Triaridis, S., Stankovic, M., Lazar, V., Chifiriuc, M. C., Vlad, M., et al. (2014). Polymicrobial wound infections: pathophysiology and current therapeutic approaches. Int. J. Pharm. 463, 119-126. doi: 10.1016/j.ijpharm. 2013.12.012

Beyenal, H., Lewandowski, Z., and Harkin, G. (2004). Quantifying biofilm structure: facts and fiction. Biofouling 20, 1-23. doi: 10.1080/ 0892701042000191628

Bilal, H., Bergen, P. J., Kim, T. H., Chung, S. E., Peleg, A. Y., Oliver, A., et al. (2019). Synergistic Meropenem-Tobramycin Combination Dosage Regimens against Clinical Hypermutable Pseudomonas aeruginosa at Simulated Epithelial Lining Fluid Concentrations in a Dynamic Biofilm Model. Antimicrob. Agents Chemother. 63:e01293-19.

Bogdanowicz, D. R., and Lu, H. H. (2013). Studying cell-cell communication in co-culture. Biotechnol. J. 8, 395-396. doi: 10.1002/biot.201300054

Boyton, R. J., Reynolds, C. J., Quigley, K. J., and Altmann, D. M. (2013). Immune mechanisms and the impact of the disrupted lung microbiome in chronic bacterial lung infection and bronchiectasis. Clin. Exp. Immunol. 171, 117-123. doi: $10.1111 /$ cei. 12003

Brown, J. L., Johnston, W., Delaney, C., Short, B., Butcher, M. C., Young, T., et al. (2019). Polymicrobial oral biofilm models: simplifying the complex. J. Med. Microbiol. 68, 1573-1584. doi: 10.1099/jmm.0.001063

Brown, R. L., Sequeira, R. P., and Clarke, T. B. (2017). The microbiota protects against respiratory infection via GM-CSF signaling. Nat. Commun. 8:1512.

Ceri, H., Olson, M. E., Stremick, C., Read, R. R., Morck, D., and Buret, A. (1999). The Calgary Biofilm Device: new technology for rapid determination of antibiotic susceptibilities of bacterial biofilms. J. Clin. Microbiol. 37, 1771-1776. doi: $10.1128 / \mathrm{jcm} .37 .6 .1771-1776.1999$

Chalmers, J. D., Goeminne, P., Aliberti, S., McDonnell, M. J., Lonni, S., Davidson, J., et al. (2014). The bronchiectasis severity index. An international derivation and validation study. Am. J. Respir. Crit. Care Med. 189, 576-585. doi: 10.1164/ rccm.201309-1575oc

Chalmers, J. D., Moffitt, K. L., Suarez-Cuartin, G., Sibila, O., Finch, S., Furrie, E., et al. (2017). Neutrophil Elastase activity is associated with exacerbations and lung function decline in bronchiectasis. Am. J. Respir. Crit. Care Med. 195, 1384-1393. doi: 10.1164/rccm.201605-1027oc

Chavant, P., Gaillard-Martinie, B., Talon, R., Hébraud, M., and Bernardi, T. (2007). A new device for rapid evaluation of biofilm formation potential by bacteria. J. Microbiol. Methods 68, 605-612. doi: 10.1016/j.mimet.2006.11.010

Cheung, J. C., Kim Chiaw, P., Pasyk, S., and Bear, C. E. (2008). Molecular basis for the ATPase activity of CFTR. Arch. Biochem. Biophys. 476, 95-100. doi: 10.1016/j.abb.2008.03.033

Clinical \& Laboratory Standards Institutes [CLSI], (2019). CLSI Microbiology Standards Subcommittees \& Resources Advancing the Field of Microbiology with Timely AST Standards. Available at: https://clsi.org/meetings/ microbiology/ (accessed December 7, 2019).

Cont, A., Rossy, T., Al-Mayyah, Z., and Persat, A. (2020). Biofilms mechanically damage epithelia by buckling. bioRxiv [Preprint]. doi: 10.1101/2020.01.29. 923060

Costa, A. N., da Costa, F. M., Campos, S. V., Salles, R. K., and Athanazio, R. A. (2018). The pulmonary microbiome: challenges of a new paradigm. J. Bras. Pneumol. 44, 424-432. doi: 10.1590/s1806-3756201700000 0209

Costello, E. K., Stagaman, K., Dethlefsen, L., Bohannan, B. J. M., and Relman, D. A. (2012). The application of ecological theory toward an understanding of the human microbiome. Science 336, 1255-1262. doi: 10.1126/science.1224203 
Costerton, J. W., Lewandowski, Z., Caldwell, D. E., Korber, D. R., and Lappin-Scott, H. M. (1995). Microbial biofilms. Annu. Rev. Microbiol. 49, 711-745.

Coyte, K. Z., Schluter, J., and Foster, K. R. (2015). The ecology of the microbiome: networks, competition, and stability. Science 350, 663-666. doi: 10.1126/ science.aad 2602

Davies, D. G., and Marques, C. N. H. (2009). A fatty acid messenger is responsible for inducing dispersion in microbial biofilms. J. Bacteriol. 191, 1393-1403. doi: 10.1128/jb.01214-08

de Dios Caballero, J., Vida, R., Cobo, M., Máiz, L., Suárez, L., Galeano, J., et al. (2017). Individual patterns of complexity in cystic fibrosis lung microbiota, including predator bacteria, over a 1-year period. mBio 8:e00959-17.

de Vos, M. G. J., Zagorski, M., McNally, A., and Bollenbach, T. (2017). Interaction networks, ecological stability, and collective antibiotic tolerance in polymicrobial infections. Proc. Natl. Acad. Sci. U.S.A. 114, 10666-10671. doi: 10.1073/pnas.1713372114

Di Poto, A., Sbarra, M. S., Provenza, G., Visai, L., and Speziale, P. (2009). The effect of photodynamic treatment combined with antibiotic action or host defence mechanisms on Staphylococcus aureus biofilms. Biomaterials 30, 3158-3166. doi: 10.1016/j.biomaterials.2009.02.038

Dickson, R. P., Erb-Downward, J. R., Freeman, C. M., McCloskey, L., Beck, J. M., Huffnagle, G. B., et al. (2015). Spatial variation in the healthy human lung microbiome and the adapted island model of lung biogeography. Ann. Am. Thorac. Soc. 12, 821-830. doi: 10.1513/annalsats.201501-029oc

Dominguez-Bello, M. G., Costello, E. K., Contreras, M., Magris, M., Hidalgo, G., Fierer, N., et al. (2010). Delivery mode shapes the acquisition and structure of the initial microbiota across multiple body habitats in newborns. Proc. Natl. Acad. Sci. U.S.A. 107, 11971-11975. doi: 10.1073/pnas.1002601107

Donlan, R. M., Piede, J. A., Heyes, C. D., Sanii, L., Murga, R., Edmonds, P., et al. (2004). Model system for growing and quantifying Streptococcus pneumoniae biofilms in situ and in real time. Appl. Environ. Microbiol. 70, 4980-4988.

Dormann, C. F., and Roxburgh, S. H. (2005). Experimental evidence rejects pairwise modelling approach to coexistence in plant communities. Proc. Biol. Sci. 272, 1279-1285. doi: 10.1098/rspb.2005.3066

Drescher, K., Shen, Y., Bassler, B. L., and Stone, H. A. (2013). Biofilm streamers cause catastrophic disruption of flow with consequences for environmental and medical systems. Proc. Natl. Acad. Sci. U.S.A. 110, 4345-4350. doi: 10.1073/ pnas. 1300321110

Dumas, A., Bernard, L., Poquet, Y., Lugo-Villarino, G., and Neyrolles, O. (2018). The role of the lung microbiota and the gut-lung axis in respiratory infectious diseases. Cell. Microbiol. 20:e12966. doi: 10.1111/cmi.12966

El Hajji, M., Harmand, J., Chaker, H., and Lobry, C. (2009). Association between competition and obligate mutualism in a chemostat. J. Biol. Dyn. 3, 635-647. doi: $10.1080 / 17513750902915978$

Erb-Downward, J. R., Thompson, D. L., Han, M. K., Freeman, C. M., McCloskey, L., Schmidt, L. A., et al. (2011). Analysis of the lung microbiome in the "healthy" smoker and in COPD. PLoS One 6:e16384. doi: 10.1371/journal.pone.0016384

Estrela, S., Trisos, C. H., and Brown, S. P. (2012). From metabolism to ecology: cross-feeding interactions shape the balance between polymicrobial conflict and mutualism. Am. Nat. 180, 566-576. doi: 10.1086/667887

Faust, K., and Raes, J. (2012). Microbial interactions: from networks to models. Nat. Rev. Microbiol. 10, 538-550. doi: 10.1038/nrmicro2832

Fernández-Olmos, A., García-Castillo, M., Maiz, L., Lamas, A., Baquero, F., and Cantón, R. (2012). In vitro prevention of Pseudomonas aeruginosa early biofilm formation with antibiotics used in cystic fibrosis patients. Int. J. Antimicrob. Agents 40, 173-176. doi: 10.1016/j.ijantimicag.2012.04.006

Filkins, L. M., Graber, J. A., Olson, D. G., Dolben, E. L., Lynd, L. R., Bhuju, S., et al. (2015). Coculture of Staphylococcus aureus with Pseudomonas aeruginosa Drives S. aureus towards Fermentative Metabolism and Reduced Viability in a Cystic Fibrosis Model. J. Bacteriol. 197, 2252-2264. doi: 10.1128/jb.00059-15

Freilich, S., Kreimer, A., Meilijson, I., Gophna, U., Sharan, R., and Ruppin, E. (2010). The large-scale organization of the bacterial network of ecological cooccurrence interactions. Nucleic Acids Res. 38, 3857-3868. doi: 10.1093/nar/ gkq118

Goeres, D. M., Hamilton, M. A., Beck, N. A., Buckingham-Meyer, K., Hilyard, J. D., Loetterle, L. R., et al. (2009). A method for growing a biofilm under low shear at the air-liquid interface using the drip flow biofilm reactor. Nat. Protoc. 4 , 783-788. doi: 10.1038/nprot.2009.59
Golding, C. G., Lamboo, L. L., Beniac, D. R., and Booth, T. F. (2016). The scanning electron microscope in microbiology and diagnosis of infectious disease. Sci. Rep. 6:26516.

Gomes, L. C., and Mergulhão, F. J. (2017). SEM analysis of surface impact on biofilm antibiotic treatment. Scanning 2017:2960194.

Gómez-Suárez, C., Busscher, H. J., and van der Mei, H. C. (2001). Analysis of bacterial detachment from substratum surfaces by the passage of air-liquid interfaces. Appl. Environ. Microbiol. 67, 2531-2537. doi: 10.1128/aem.67.6. 2531-2537.2001

Greulich, P., Scott, M., Evans, M. R., and Allen, R. J. (2015). Growth-dependent bacterial susceptibility to ribosome-targeting antibiotics. Mol. Syst. Biol. 11:796. doi: $10.15252 / \mathrm{msb} .20145949$

Guggino, W. B., and Banks-Schlegel, S. P. (2004). Macromolecular interactions and ion transport in cystic fibrosis. Am. J. Respir. Crit. Care Med. 170, 815-820. doi: 10.1164/rccm.200403-381ws

Haller, D., Bode, C., Hammes, W. P., Pfeifer, A. M., Schiffrin, E. J., and Blum, S. (2000). Non-pathogenic bacteria elicit a differential cytokine response by intestinal epithelial cell/leucocyte co-cultures. Gut 47, 79-87. doi: 10.1136/gut. 47.1.79

Hansen, S. H., Kabbeck, T., Radtke, C. P., Krause, S., Krolitzki, E., Peschke, T., et al. (2019). Machine-assisted cultivation and analysis of biofilms. Sci. Rep. 9:8933.

Harrison, J. J., Stremick, C. A., Turner, R. J., Allan, N. D., Olson, M. E., and Ceri, H. (2010). Microtiter susceptibility testing of microbes growing on peg lids: a miniaturized biofilm model for high-throughput screening. Nat. Protoc. 5, 1236-1254. doi: 10.1038/nprot.2010.71

Hartmann, R., Jeckel, H., Jelli, E., Singh, P. K., Vaidya, S., Bayer, M., et al. (2019). BiofilmQ, a software tool for quantitative image analysis of microbial biofilm communities. bioRxiv [Preprint]. doi: 10.1101/735423

Hasin, Y., Seldin, M., and Lusis, A. (2017). Multi-omics approaches to disease. Genome Biol. 18:83.

Hendriksen, R. S., Bortolaia, V., Tate, H., Tyson, G. H., Aarestrup, F. M., and McDermott, P. F. (2019). Using genomics to track global antimicrobial resistance. Front. Public Health 7:242. doi: 10.3389/fpubh.2019.00242

Hilty, M., Burke, C., Pedro, H., Cardenas, P., Bush, A., Bossley, C., et al. (2010). Disordered microbial communities in asthmatic airways. PLoS One 5:e8578. doi: 10.1371/journal.pone.0008578

Hindré, T., Knibbe, C., Beslon, G., and Schneider, D. (2012). New insights into bacterial adaptation through in vivo and in silico experimental evolution. Nat. Rev. Microbiol. 10, 352-365. doi: 10.1038/nrmicro2750

Huang, Y., Chakraborty, S., and Liang, H. (2020). Methods to probe the formation of biofilms: applications in foods and related surfaces. Anal. Methods 12, 416-432. doi: 10.1039/c9ay02214g

Huang, Y. J., and LiPuma, J. J. (2016). The microbiome in cystic fibrosis. Clin. Chest Med. 37, 59-67.

Ingenito, E. P., Solway, J., McFadden, E. R., Pichurko, B., Bowman, H. F., Michaels, D., et al. (1987). Indirect assessment of mucosal surface temperatures in the airways: theory and tests. J. Appl. Physiol. 63, 2075-2083. doi: 10.1152/jappl. 1987.63.5.2075

Jass, J., Costerton, J. W., and Lappin-Scott, H. M. (1995). Assessment of a chemostat-coupled modified Robbins device to study biofilms. J. Ind. Microbiol. 15, 283-289. doi: 10.1007/bf01569981

Jia, L., Gu, W., Zhang, Y., Ji, Y., Liang, J., Wen, Y., et al. (2017). The Crosstalk between HDPSCs and HUCMSCs on proliferation and osteogenic genes expression in coculture system. Int. J. Med. Sci. 14, 1118-1129. doi: 10.7150/ ijms. 19814

Jones, J. A., and Wang, X. (2018). Use of bacterial co-cultures for the efficient production of chemicals. Curr. Opin. Biotechnol. 53, 33-38. doi: 10.1016/j. copbio.2017.11.012

Khan, N., Vidyarthi, A., Nadeem, S., Negi, S., Nair, G., and Agrewala, J. N. (2016). Alteration in the gut microbiota provokes susceptibility to tuberculosis. Front. Immunol. 7:529. doi: 10.3389/fimmu.2016.00529

Kim, J., Hegde, M., and Jayaraman, A. (2010). Co-culture of epithelial cells and bacteria for investigating host-pathogen interactions. Lab Chip 10, 43-50. doi: $10.1039 / \mathrm{b} 911367 \mathrm{c}$

Klepac-Ceraj, V., Lemon, K. P., Martin, T. R., Allgaier, M., Kembel, S. W. Knapp, A. A., et al. (2010). Relationship between cystic fibrosis respiratory tract bacterial communities and age, genotype, antibiotics and Pseudomonas 
aeruginosa. Environ. Microbiol. 12, 1293-1303. doi: 10.1111/j.1462-2920.2010. 02173.x

Kneitel, J. M., and Chase, J. M. (2004). Trade-offs in community ecology: linking spatial scales and species coexistence. Ecol. Lett. 7, 69-80. doi: 10.1046/j.14610248.2003.00551.x

Knippenberg, S., Ueberberg, B., Maus, R., Bohling, J., Ding, N., Tort Tarres, M., et al. (2015). Streptococcus pneumoniae triggers progression of pulmonary fibrosis through pneumolysin. Thorax 70, 636-646. doi: 10.1136/thoraxjnl2014-206420

Krohn-Molt, I., Wemheuer, B., Alawi, M., Poehlein, A., Güllert, S., Schmeisser, C., et al. (2013). Metagenome survey of a multispecies and alga-associated biofilm revealed key elements of bacterial-algal interactions in photobioreactors. Appl. Environ. Microbiol. 79, 6196-6206. doi: 10.1128/aem.01641-13

Lebeaux, D., Chauhan, A., Rendueles, O., and Beloin, C. (2013). From in vitro to in vivo models of bacterial biofilm-related infections. Pathogens 2, 288-356. doi: 10.3390/pathogens2020288

Lee, S. H., Lee, Y., Park, J. S., Cho, Y.-J., Yoon, H. I., Lee, C.-T., et al. (2018). Characterization of microbiota in bronchiectasis patients with different disease severities. J. Clin. Med. 7:429. doi: 10.3390/jcm7110429

Limoli, D. H., Whitfield, G. B., Kitao, T., Ivey, M. L., Davis, M. R., Grahl, N., et al. (2017). Pseudomonas aeruginosa alginate overproduction promotes coexistence with Staphylococcus aureus in a model of cystic fibrosis respiratory infection. mBio 8:e00186-17.

Liu, W., Jacquiod, S., Brejnrod, A., Russel, J., Burmølle, M., and Sørensen, S. J. (2019). Deciphering links between bacterial interactions and spatial organization in multispecies biofilms. ISME J. 13, 3054-3066. doi: 10.1038/ s41396-019-0494-9

Lopes, S. P., Azevedo, N. F., and Pereira, M. O. (2018). Quantitative assessment of individual populations within polymicrobial biofilms. Sci. Rep. 8:9494.

Lotka, J. (1922). Natural selection as a physical principle. Proc. Natl. Acad. Sci. U.S.A. 8, 151-154. doi: 10.1073/pnas.8.6.151

Macià, M. D., Rojo-Molinero, E., and Oliver, A. (2014). Antimicrobial susceptibility testing in biofilm-growing bacteria. Clin. Microbiol. Infect. 20, 981-990. doi: 10.1111/1469-0691.12651

Mammen, M. J., and Sethi, S. (2017). Microbiome in chronic lung diseases. BRN Rev. 3, 102-120.

Marques, C. N. H., Morozov, A., Planzos, P., and Zelaya, H. M. (2014). The fatty acid signaling molecule cis-2-decenoic acid increases metabolic activity and reverts persister cells to an antimicrobial-susceptible state. Appl. Environ. Microbiol. 80, 6976-6991. doi: 10.1128/aem.01576-14

Marshall, B. E. A., Petren, K., Rizvi, S., Fink, A., Ostrenga, J., Sewall, A., et al. (2016). Annual Data Report 2015. Cystic Fibrosis Foundation Patient Registry. Available at: https://www.cff.org/our-research/cf-patient-registry/2015-patient-registryannual-data-report.pdf (accessed August 5, 2019).

May, R. M. (1973). Stability and complexity in model ecosystems. Monogr. Popul. Biol. 6, 37-78.

Melaugh, G., Hutchison, J., Kragh, K. N., Irie, Y., Roberts, A., Bjarnsholt, T., et al. (2016). Shaping the growth behaviour of biofilms initiated from bacterial aggregates. PLoS One 11:e0149683. doi: 10.1371/journal.pone.0149683

Momeni, B., Xie, L., and Shou, W. (2017). Lotka-Volterra pairwise modeling fails to capture diverse pairwise microbial interactions. eLife 6:e25051.

Moreau-Marquis, S., Stanton, B. A., and O’Toole, G. A. (2008). Pseudomonas aeruginosa biofilm formation in the cystic fibrosis airway. Pulm. Pharmacol. Ther. 21, 595-599. doi: 10.1016/j.pupt.2007.12.001

Moree, W. J., Phelan, V. V., Wu, C.-H., Bandeira, N., Cornett, D. S., Duggan, B. M., et al. (2012). Interkingdom metabolic transformations captured by microbial imaging mass spectrometry. Proc. Natl. Acad. Sci. U.S.A. 109, 13811-13816. doi: $10.1073 /$ pnas. 1206855109

Morris, A., Beck, J. M., Schloss, P. D., Campbell, T. B., Crothers, K., Curtis, J. L., et al. (2013). Comparison of the respiratory microbiome in healthy nonsmokers and smokers. Am. J. Respir. Crit. Care Med. 187, 10671075 .

Naik, S., Bouladoux, N., Wilhelm, C., Molloy, M. J., Salcedo, R., Kastenmuller, W., et al. (2012). Compartmentalized control of skin immunity by resident commensals. Science 337, 1115-1119. doi: 10.1126/science.1225152

Orazi, G., and O'Toole, G. A. (2017). Pseudomonas aeruginosa Alters Staphylococcus aureus sensitivity to vancomycin in a biofilm model of cystic fibrosis infection. mBio 8:e00873-17.
O’Toole, G. A., and Kolter, R. (1998). Flagellar and twitching motility are necessary for Pseudomonas aeruginosa biofilm development. Mol. Microbiol. 30, 295-304. doi: 10.1046/j.1365-2958.1998.01062.x

Pacheco, D. P., Butnarasu, C. S., Briatico Vangosa, F., Pastorino, L., Visai, L., Visentin, S., et al. (2019). Disassembling the complexity of mucus barriers to develop a fast screening tool for early drug discovery. J. Mater. Chem. B Mater. Biol. Med. 7, 4940-4952. doi: 10.1039/c9tb00957d

Pallavicini, P., Arciola, C. R., Bertoglio, F., Curtosi, S., Dacarro, G., D’Agostino, A., et al. (2017). Silver nanoparticles synthesized and coated with pectin: An ideal compromise for anti-bacterial and anti-biofilm action combined with woundhealing properties. J. Colloid Interface Sci. 498, 271-281. doi: 10.1016/j.jcis. 2017.03.062

Pamp, S. J., Sternberg, C., and Tolker-Nielsen, T. (2009). Insight into the microbial multicellular lifestyle via flow-cell technology and confocal microscopy. Cytometry A 75, 90-103. doi: 10.1002/cyto.a.20685

Parker, A. E., Walker, D. K., Goeres, D. M., Allan, N., Olson, M. E., and Omar, A. (2014). Ruggedness and reproducibility of the MBEC biofilm disinfectant efficacy test. J. Microbiol. Methods 102, 55-64.

Peterson, B. W., He, Y., Ren, Y., Zerdoum, A., Libera, M. R., Sharma, P. K., et al. (2015). Viscoelasticity of biofilms and their recalcitrance to mechanical and chemical challenges. FEMS Microbiol. Rev. 39, 234-245.

Pritt, B., O’Brien, L., and Winn, W. (2007). Mucoid Pseudomonas in cystic fibrosis. Am. J. Clin. Pathol. 128, 32-34.

Purevdorj, B., Costerton, J. W., and Stoodley, P. (2002). Influence of hydrodynamics and cell signaling on the structure and behavior of Pseudomonas aeruginosa biofilms. Appl. Environ. Microbiol. 68, 4457-4464.

Raimbault, M. (1998). General and microbiological aspects of solid substrate fermentation. Electron. J. Biotechnol. 1, 174-188.

Ren, D., Madsen, J. S., de la Cruz-Perera, C. I., Bergmark, L., Sørensen, S. J., and Burmølle, M. (2014). High-throughput screening of multispecies biofilm formation and quantitative PCR-based assessment of individual species proportions, useful for exploring interspecific bacterial interactions. Microb. Ecol. 68, 146-154.

Røder, H. L., Sørensen, S. J., and Burmølle, M. (2016). Studying bacterial multispecies biofilms: where to start? Trends Microbiol. 24, 503-513.

Rogers, G. B., Zain, N. M. M., Bruce, K. D., Burr, L. D., Chen, A. C., Rivett, D. W., et al. (2014). A novel microbiota stratification system predicts future exacerbations in bronchiectasis. Ann. Am. Thorac. Soc. 11, 496-503.

Rusconi, R., Garren, M., and Stocker, R. (2014). Microfluidics expanding the frontiers of microbial ecology. Annu. Rev. Biophys. 43, 65-91.

Schuijt, T. J., Lankelma, J. M., Scicluna, B. P., de Sousa e Melo, F., Roelofs, J. J. T. H., de Boer, J. D., et al. (2016). The gut microbiota plays a protective role in the host defence against pneumococcal pneumonia. Gut 65, 575-583.

Segal, L. N., Alekseyenko, A. V., Clemente, J. C., Kulkarni, R., Wu, B., Gao, Z., et al. (2013). Enrichment of lung microbiome with supraglottic taxa is associated with increased pulmonary inflammation. Microbiome 1:19.

Segal, L. N., Clemente, J. C., Wu, B. G., Wikoff, W. R., Gao, Z., Li, Y., et al. (2017). Randomised, double-blind, placebo-controlled trial with azithromycin selects for anti-inflammatory microbial metabolites in the emphysematous lung. Thorax 72, 13-22.

Sharma, M., Visai, L., Bragheri, F., Cristiani, I., Gupta, P. K., and Speziale, P. (2008). Toluidine blue-mediated photodynamic effects on staphylococcal biofilms. Antimicrob. Agents Chemother. 52, 299-305.

Sherrard, L. J., Einarsson, G. G., Johnston, E., O’Neill, K., McIlreavey, L., McGrath, S. J., et al. (2019). Assessment of stability and fluctuations of cultured lower airway bacterial communities in people with cystic fibrosis. J. Cyst. Fibros 18, $808-816$.

Sissons, C. H. (1997). Artificial dental plaque biofilm model systems. Adv. Dent. Res. 11, 110-126.

Solé, R. V., and Bascompte, J. (2012). Self-Organization in Complex Ecosystems. Princeton, NJ: Princeton University Press.

Sorek, R., and Cossart, P. (2010). Prokaryotic transcriptomics: a new view on regulation, physiology and pathogenicity. Nat. Rev. Genet. 11, 9-16.

Speirs, D. C., Smith, H. L., and Waltman, P. (1996). The theory of the chemostat: dynamics of microbial competition. J. Appl. Ecol. 33:651.

Stoodley, P., Cargo, R., Rupp, C. J., Wilson, S., and Klapper, I. (2002). Biofilm material properties as related to shear-induced deformation and detachment phenomena. J. Ind. Microbiol. Biotechnol. 29, 361-367. 
Surette, M. G. (2014). The cystic fibrosis lung microbiome. Ann. Am. Thorac. Soc. 11(Suppl. 1), S61-S65.

Swenson, C., Schraufnagel, D., and Sadikot, R. (2017). What is Bronchiectasis? Am. J. Respir. Crit. Care Med. 195, 15-16.

Sze, M. A., Dimitriu, P. A., Suzuki, M., McDonough, J. E., Campbell, J. D., Brothers, J. F., et al. (2015). Host response to the lung microbiome in chronic obstructive pulmonary disease. Am. J. Respir. Crit. Care Med. 192, $438-445$.

Taylor, S. L., Rogers, G. B., Chen, A. C.-H., Burr, L. D., McGuckin, M. A., and Serisier, D. J. (2015). Matrix metalloproteinases vary with airway microbiota composition and lung function in non-cystic fibrosis bronchiectasis. Ann. Am. Thorac. Soc. 12, 701-707.

Tognon, M., Köhler, T., Gdaniec, B. G., Hao, Y., Lam, J. S., Beaume, M., et al. (2017). Co-evolution with Staphylococcus aureus leads to lipopolysaccharide alterations in Pseudomonas aeruginosa. ISME J. 11, 2233-2243.

Tognon, M., Köhler, T., Luscher, A., and van Delden, C. (2019). Transcriptional profiling of Pseudomonas aeruginosa and Staphylococcus aureus during in vitro co-culture. BMC Genomics 20:30. doi: 10.1186/s12864-018-5398-y

Tunney, M. M., Einarsson, G. G., Wei, L., Drain, M., Klem, E. R., Cardwell, C., et al. (2013). Lung microbiota and bacterial abundance in patients with bronchiectasis when clinically stable and during exacerbation. Am. J. Respir. Crit. Care Med. 187, 1118-1126.

Tuson, H. H., Renner, L. D., and Weibel, D. B. (2012). Polyacrylamide hydrogels as substrates for studying bacteria. Chem. Commun. 48, 1595-1597.

Van den Driessche, F., Rigole, P., Brackman, G., and Coenye, T. (2014). Optimization of resazurin-based viability staining for quantification of microbial biofilms. J. Microbiol. Methods 98, 31-34.

Venkataraman, A., Bassis, C. M., Beck, J. M., Young, V. B., Curtis, J. L., Huffnagle, G. B., et al. (2015). Application of a neutral community model to assess structuring of the human lung microbiome. mBio 6:e02284-14.

Vet, S., de Buyl, S., Faust, K., Danckaert, J., Gonze, D., and Gelens, L. (2018). Bistability in a system of two species interacting through mutualism as well as competition: Chemostat vs. Lotka-Volterra equations. PLoS One 13:e197462. doi: 10.1371/journal.pone.0197462

Volterra, V. (1928). Variations and fluctuations of the number of individuals in Animal species living together. ICES J. Mar. Sci. 3, 3-51.

Vuornos, K., Ojansivu, M., Koivisto, J. T., Häkkänen, H., Belay, B., Montonen, T., et al. (2019). Bioactive glass ions induce efficient osteogenic differentiation of human adipose stem cells encapsulated in gellan gum and collagen type I hydrogels. Mater. Sci. Eng. C Mater. Biol. Appl. 99, 905-918.
Wang, Y., and Wu, H. (2011). A mutualism-competition model characterizing competitors with mutualism at low density. Math. Comput. Model. 53, 16541663.

Wang, Z., Bafadhel, M., Haldar, K., Spivak, A., Mayhew, D., Miller, B. E., et al. (2016). Lung microbiome dynamics in COPD exacerbations. Eur. Respir. J. 47, 1082-1092.

West, J. B. (1968). Regional differences in the lung. Postgrad. Med. J. 44, 120-122. Wimpenny, J. W. (1997). The validity of models. Adv. Dent. Res. 11, 150-159.

Woods, J., Boegli, L., Kirker, K. R., Agostinho, A. M., Durch, A. M., Delancey Pulcini, E., et al. (2012). Development and application of a polymicrobial, in vitro, wound biofilm model. J. Appl. Microbiol. 112, 998-1006.

Woods, P. W., Haynes, Z. M., Mina, E. G., and Marques, C. N. H. (2018). Maintenance of S. aureus in co-culture with $P$. aeruginosa while growing as biofilms. Front. Microbiol. 9:3291. doi: 10.3389/fmicb.2018.03291

Woodworth, B. A., Tamashiro, E., Bhargave, G., Cohen, N. A., and Palmer, J. N. (2008). An in vitro model of Pseudomonas aeruginosa biofilms on viable airway epithelial cell monolayers. Am. J. Rhinol. 22, 235-238.

Yates, J. R., Ruse, C. I., and Nakorchevsky, A. (2009). Proteomics by mass spectrometry: approaches, advances, and applications. Annu. Rev. Biomed. Eng. 11, 49-79.

Yin, L., Wei, H., Liang, S., and Yu, X. (2017). From the cover: an animal-free in vitro three-dimensional testicular cell coculture model for evaluating male reproductive toxicants. Toxicol. Sci. 159, 307-326.

Zemanick, E. T., Wagner, B. D., Robertson, C. E., Ahrens, R. C., Chmiel, J. F., Clancy, J. P., et al. (2017). Airway microbiota across age and disease spectrum in cystic fibrosis. Eur. Respir. J. 50:1700832.

Zhang, K., Fujita, Y., Chang, L., Qu, Y., Pu, Y., Wang, S., et al. (2019). Abnormal composition of gut microbiota is associated with resilience versus susceptibility to inescapable electric stress. Transl. Psychiatry 9:231.

Conflict of Interest: The authors declare that the research was conducted in the absence of any commercial or financial relationships that could be construed as a potential conflict of interest.

Copyright (c) 2020 Oriano, Zorzetto, Guagliano, Bertoglio, van Uden, Visai and Petrini. This is an open-access article distributed under the terms of the Creative Commons Attribution License (CC BY). The use, distribution or reproduction in other forums is permitted, provided the original author(s) and the copyright owner(s) are credited and that the original publication in this journal is cited, in accordance with accepted academic practice. No use, distribution or reproduction is permitted which does not comply with these terms. 